\title{
The UK is the Eurozone's Dumping Ground
}

\author{
David Blake*
}

City, University of London, 106 Bunhill Row, London, EC1Y 8TZ, United Kingdom.

\begin{abstract}
The European Union is dumping its goods on world markets, especially in the UK, because the euro is a structurally undervalued currency. First, the euro is an 'incomplete' currency. Unlike every other currency, there is no single sovereign standing behind it. Each member state of the Eurozone is 'sub-sovereign', since it stands behind the euro only to a certain percentage and, collectively, the member states do not share joint-and-several liability. Second, the euro is an artificially 'constructed' currency, as a consequence of the fixed rates used when it was introduced in 1999 to convert the domestic currencies of EZ members into euros. This affected not only the internal exchange rates between the EZ members, but also the international value of the euro. The net result has been a downward bias in the international trading value of the euro, with the inefficient southern member states dragging down the value of the euro relative to what it would be if all member states were as efficient as Germany and the Netherlands.

The euro is undervalued against sterling on a purchasing power parity (PPP) basis by between $15.2 \%$ and $20 \%$. As a consequence, the UK has almost always run a trade deficit with the EU over the period after the introduction of the euro. In 2019, the UK ratio of exports to imports with the EU was only $79 \%$. While the UK maintains the close economic ties with the EU that the EU wants, the UK will remain a captive market for EZ member goods. Had the euro been correctly valued, then EZ exports to the UK in 2018 would have been lower by between $£ 67.2 \mathrm{bn}$ and $£ 88.4 \mathrm{bn}$. The UK would therefore be entitled to impose an annual anti-dumping duty on the EZ in the range $£ 67.2 \mathrm{bn}-$ $£ 88.4$ bn.

Ursula von der Leyen says the EU is 'ready to design a new partnership with zero tariffs, zero quotas, zero dumping' with the UK. It is quite remarkable that the new German president of the European Commission calls for zero dumping, when her own country is one of the world's biggest dumpers of goods onto world markets.

The EU is following a classic 'beggar thy neighbour' strategy with its trading partners, in particular the UK, by exploiting the euro's structural undervaluation.
\end{abstract}

Keywords: Euro, Purchasing Power Parity, Dumping.

JEL: F31, F33, F51.

\section{INTRODUCTION}

The European Union (EU) is seeking a 'level playing field' with the UK after Brexit. ${ }^{1}$ One of the key issues concerning the EU is 'dumping'. It is concerned that the UK becomes a super-competitive, de-regulated 'Singapore-on-Thames' that undercuts the prices of products produced in the EU, in the same way that China does. However, the opposite is the

*Address correspondence to this author at City, University of London, 106 Bunhill Row, London, EC1Y 8TZ, United Kingdom;

Email: d.blake@city.ac.uk

1See, e.g., David Blake (2020) Ensuring a genuine level playing field with the EU post-brexit, Briefings for Britain, 28 February; https://briefingsforbritain.co.uk/ensuring-a-genuine-level-playing-fieldwith-the-eu-post-brexit/ case. It is the nineteen EU member states operating a single currency, the euro, in the Eurozone (EZ), ${ }^{2}$ that are dumping their goods onto world markets - in particular the UK - because the euro is a structurally undervalued currency.

The global economic and financial community regards the euro as just another currency. However, the euro is not 'just another currency'. First, it is an 'incomplete' currency. Unlike every other currency, there is no single sovereign standing behind it. Each member state stands behind the euro only to

2Nineteen of the 27 existing EU member states are in the Eurozone: Austria, Belgium, Cyprus, Estonia, Finland, France, Germany, Greece, Ireland, Italy, Latvia, Lithuania, Luxembourg, Malta, the Netherlands, Portugal, Slovakia, Slovenia, and Spain. Denmark opted out. Bulgaria, Croatia, the Czech Republic, Hungary, Poland, Romania and Sweden are not in the Eurozone. The UK, while it was an EU member, also opted out of the euro. 
a certain percentage ${ }^{3}$ and collectively the member states do not share joint-and-several liability. This makes them 'subsovereign $^{14}$ members of the EZ. Second, it is an artificially 'constructed' currency, as a consequence of the fixed rates used when it was introduced in 1999 to convert the domestic currencies of EZ members into euros. This affected not only the internal exchange rates between the EZ members, but also the international value of the euro.

Some member states, e.g., Italy and Spain, joined the euro at a conversion rate that turned out to be too high, given the subsequent performance of their economies. The original supporters of the euro project believed that competition would lead to this effect tapering away by virtue of what they predicted would be a productivity catch-up, but this never happened. As a result, these countries have experienced persistent structural trade deficits with some other members (for some or all of the period since the euro was introduced). Under such circumstances, normal countries could devalue their nominal exchange rate, but this option is not available to EZ members. By contrast, other member states, e.g., Germany and the Netherlands, joined the euro at a conversion rate that turned out to be too low, given the subsequent performance of their economies. These countries then experienced persistent structural trade surpluses with some other members, which would normally be eliminated by an appreciation of their 'domestic' currency - but again this is no longer possible. ${ }^{5}$

The net result has been a downward bias in the international trading value of the euro, with the inefficient southern member states dragging down the value of the euro relative to what it would be if all member states were as efficient as Germany and the Netherlands. This has resulted in a persistent undervaluation of the euro for the strongest economies in the EZ.

A normal sovereign stands fully behind the debts that it issues because of its power to raise taxes and because of its ability to print enough of its currency to pay back the debts in the absence of sufficient tax raising capacity. By contrast, EZ member states, while they behave like a single sovereign state, are not jointly-and-severally liable for each other's debts, and do not have sufficient tax raising powers or the ability to print sufficient euros to pay off their total debts in full - because one country in particular, Germany, will not permit the monetisation of national debts in the EU. ${ }^{6}$ As a

3 Equal to that state's capital key in the European Central Bank: https://www.ecb.europa.eu/ecb/orga/capital/html/index.en.html.

4 A term coined by Barnabas Reynolds, David Blake, and Robert Lyddon (2020) Managing Euro Risk, Politeia, 27 February 2020.

5 It is important to note that, while EZ member states can no longer alter their nominal exchange rates with other member states, their real exchange rates will change when wages and prices change at a different rate from other member states.

6 Germany was behind:

- the Fiscal Stability Treaty (formally the Treaty on Stability, Coordination and Governance in the Economic and Monetary Union (TSCG)) which aims to strengthen fiscal discipline in the EZ via a balanced budget rule and an automatic correction mechanism;

https://www.ecb.europa.eu/pub/pdf/other/mb201203_focus12.en. pdf; result, all EZ member states benefit from a structurally undervalued currency without 'paying' the full set of costs. This is essentially a structural form of currency manipulation, no different in principle from how some countries engage more directly in currency manipulation to lower the international value of their currency.

The euro's relative undervaluation - for the mainly northern member states - benefits EZ exporters. This, in turn, has led to persistent structural international trade surpluses being achieved by these states. However, the weakness of many mainly southern EZ economies - arising in part due to their very EZ membership - needed vast amounts of quantitative easing $(\mathrm{QE})^{7}$ to ameliorate, putting further downward pressure on the euro's value.

In recent years, world attention - especially in the US - has been focused on currency undervaluation, currency manipulation, dumping and trade imbalances for one global currency, namely the Chinese renminbi (RMB) ${ }^{8}$ The remedies proposed have included the imposition of duties on countries that engage in these practices on the grounds that they constitute unfair trade, permitting retaliation in the form of tariffs. $^{9}$

However, the euro has escaped this attention, including by most academic economists. One of the few papers on the topic is by Stefan Kawalec, a former vice-minister of finance of Poland. Writing in 2015, he said: ${ }^{10}$

In 2014, the Eurozone, with its huge current account surplus, was a major source of global economic imbalances. This phenomenon could last for a long time. Monetary expansion, which leads to currency depreciation, is the only macroeconomic tool available to the European Central Bank (ECB) to

- Article 123 of the Treaty on the Functioning of the European Union (TFEU) which prohibits any form of monetary financing of public debt or deficits:

- Article 125 of the TFEU (the 'no-bail-out clause') which precludes one member state from becoming liable for the liabilities of another member state. See Peter Praet (2012) The role of the central bank and euro area governments in times of crisis, 19 April;

https://www.ecb.europa.eu/press/key/date/2012/html/sp120419.e n.html

7 Ritvik Carvalho, Dhara Ranasinghe, and Tommy Wilkes (2018) The life and times of ECB quantitative easing, 2015-18, Reuters, 12 December; https://www.reuters.com/article/us-eurozone-ecb-qe/the-life-and-times-ofecb-quantitative-easing-2015-18-iduskbn1ob1sm.

8 See for example: Wayne M. Morrison (2019) China's Currency Policy, CRS In Focus, IF10139, 24 May; https://fas.org/sgp/crs/row/IF10139.pdf. 9 See for example:

- Department of Commerce (2019), Proposed Rule to Allow Currency Manipulation and Undervaluation as Countervailable Subsidy, Thompson Hine LLP, 24 May; https://www.lexology.com/library/detail.aspx?g=0b60b8a9-23f048f7-b812-a4ea23870951;

- Andrea Shalal (2020), U.S. finalizes rule to slap duties on countries that undervalue currencies, Reuters Business News, 4 February; https://www.reuters.com/article/us-usa-trade-currency/u-sfinalizes-rule-to-slap-duties-on-countries-that-undervaluecurrencies-idUSKBN1ZY08V.

10 Stefan Kawalec (2015), The permanent necessity to undervalue the euro endangers Europe's trade relations, 12th EUROFRAME Conference on Economic Policy Issues in the European Union, June; https://www.euroframe.org/files/user_upload/euroframe/docs/2015/conferen ce/Session\%203/EUROF15_Kawalec.pdf. 
boost the competitiveness of struggling southern economies. With the current economic imbalances within the Eurozone, the elimination the Eurozone's current account surplus through appreciation of the euro would aggravate economic conditions in struggling member countries and could be politically explosive. Some observers hope that the Eurozone's internal imbalances can be reduced by more expansionary policies in Germany or, in the future, by wealth transfers to be enabled when the fiscal and political union materialises. Both hopes are unjustified. A huge Eurozone current account surplus is likely to persist, and this will lead to tensions with the US and other trade partners.

We will now provide evidence demonstrating the euro's structural incompleteness and undervaluation (section 2) and the economic consequences of this for the EZ's trading partners, in particular, the UK (section 3). We will then consider what remedies these trading partners can use to counter this undervaluation (section 4) before concluding (section 5).

\section{THE STRUCTURAL INCOMPLETENESS OF THE EURO}

Managing Euro Risk ${ }^{11}$ explained how the EZ's euro's structure means that member states of the EZ are not sovereign over their domestic currency and are, in effect, using a 'foreign' currency. This is because:

- since no member state individually controls the European Central Bank (ECB), EZ members are 'subsovereign', implying that the member states do not (and cannot) stand behind their government debts or currency in the way genuine sovereigns do, by printing more money to repay their debts when their tax base proves to be insufficient;

- there is no joint-and-several liability between member states or lender of last resort;

- there is no EZ-wide bank deposit insurance scheme;

- the EZ's banks are generally weak with no crossborder mergers to increase the strength of the banking system;

- as a result, the debt of member states and their public sector entities cannot be treated as sovereign quality;

- yet the EU treats this debt as of sovereign quality throughout the EU as a matter of law;

- this means the entire EZ financial system is undercapitalised, under-collateralised and with lower liquidity than required by the international standards set by the Basel Rules; ${ }^{12}$

- the position is made worse by the high percentage of non-performing bank loans, especially in Italy, Greece and Cyprus;

11 See Barnabas Reynolds, David Blake, and Robert Lyddon (2020) Managing Euro Risk, Politeia, 27 February;

https://www.politeia.co.uk/managing-euro-risk-saving-investors-from-

systemic-risk-by-barnabas-reynolds-david-blake-and-robert-lyddon/

12 Basel III: international regulatory framework for banks;

https://www.bis.org/bcbs/basel3.htm
- matters are further exacerbated by a lack of transparency and bad accounting practices, leading to collateral and liquidity problems when EZ member state government bonds are used on one side of international transactions, executed through, for example, central counterparties $;^{13}$

- as a result, the euro currency operates with vast amounts of unmanaged financial risk;

- this risk is passed into the global financial and economic system through international trading, investment and bank lending activities.

The underlying cause of this is the separation of the ECB from national member state sovereignty, meaning that no individual state can print euros independently and when euro interest rates are set, they are set by a committee in which no member state has a majority. If any one of those states finds itself in a position where it is unable to repay its debts from taxation or replacement borrowing, it depends on the willingness of other EZ member states to lend the money to do so - in effect by printing more euros. As a result of the structurally incomplete euro currency, with no single sovereign backer, each member state of the EZ is in effect using and financing itself in a foreign currency.

The consequence of this is that the economically stronger EZ member states use a structurally undervalued currency, gaining the full benefits of a single currency, but without the cost that any normal currency requires - which is to stand behind the currency in full in all economic and financial circumstances. In short, the euro is a currency constructed on the cheap - and the rest of the world pays the price. It also means that the risks from an under-capitalised and undercollateralised EZ financial system could be transmitted to the global markets through a domino effect, as explained in Managing Euro Risk. To the extent that the forex markets recognise these risks, the euro should trade at an even lower value than otherwise.

\section{ECONOMIC CONSEQUENCES OF THE EURO'S STRUCTURAL INCOMPLETENESS ${ }^{14}$}

The Organisation for Economic Cooperation and Development (OECD) defines dumping as 'the practice by firms of selling products abroad at below costs or significantly below prices in the home market. The former implies predatory pricing; the latter, price discrimination'. ${ }^{15}$ This definition needs to be understood in the case of EZ countries as extending to 'the practice by a country of selling products abroad at artificially low prices due to the distorted international value of its currency', which in international law, as will be seen, amounts to dumping also.

In 2019, Germany had the world's largest current account surplus - which measures the net flow of goods, services and investments - at $\$ 276 \mathrm{bn}$. It was the fourth consecutive year

13 Also known as clearing houses.

14 I am grateful to Professor Kevin Dowd, Professor Patrick Minford, Dr Graham Gudgin, and Lord Peter Lilley for their comments on this section. The usual caveat applies.

15 https://stats.oecd.org/glossary/detail.asp? $\mathrm{ID}=3201$. 
Table 1. Weights of the Original 11 Constituent Currencies of the Euro.

\begin{tabular}{|c|c|c|c|c|c|c|c|c|c|c|}
\hline Currency & FRF & ITL & ESP & NLG & BEF & IE£ & FIM & ATS & PTE & DEM \\
\hline
\end{tabular}

Table 2. Average Annual Growth Rate in Productivity of the Original 11 Eurozone Members, 1995-2005.

\begin{tabular}{|c|c|c|c|c|c|c|c|c|c|c|}
\hline Country & FRA & ITA & ESP & NLD & BEL & IRL & FIN & AUT & PT & DEU \\
\hline Productivity growth (\%pa) & 1.8 & 0.5 & 0.0 & 1.7 & NA & NA & 2.6 & 1.8 & NA & 1.9 \\
\hline
\end{tabular}

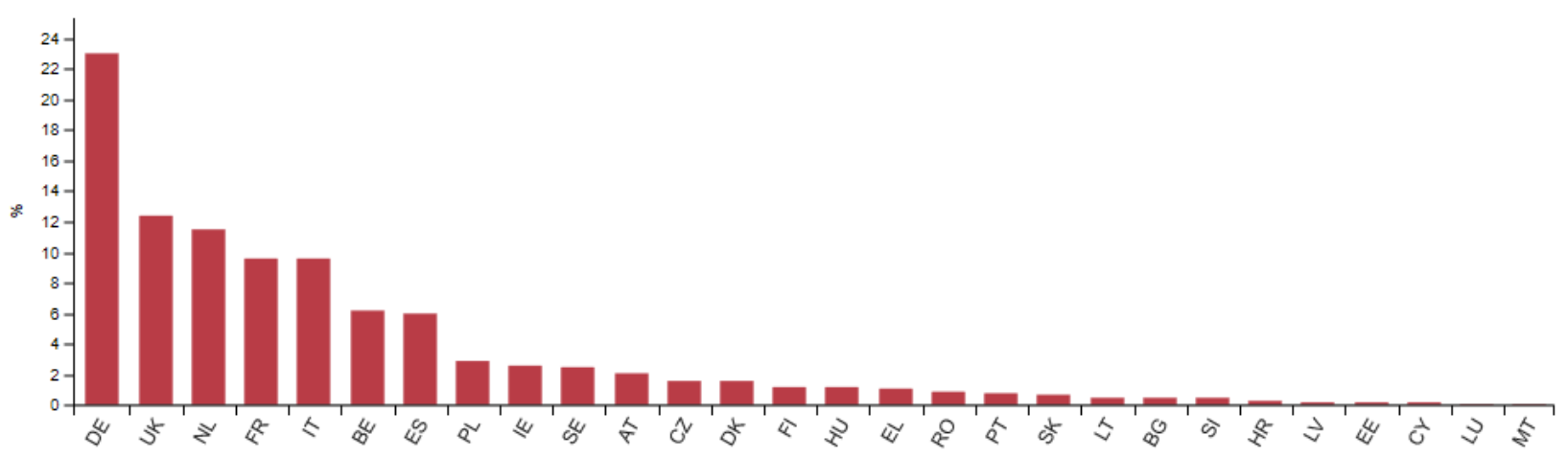

Fig. (1). Exports of goods to other member states, 2018 (\% of total intra-EU exports).

that it held this record. ${ }^{16}$ The explanation for this is the way in which the euro and EZ were set up in 1999. Table 1 shows the weights of the 11 original constituent currencies of the euro. ${ }^{17}$

Over a third $(34.38 \%)$ of the value of the euro is represented by the Deutschmark (DEM). If all 11 members were equally productive, the particular weights would not matter, because very quickly each would converge to the same structural valuation. But this has not been the case. Table 2 shows the average annual growth rate in productivity of the $11 \mathrm{mem}-$ bers between 1995-2005. ${ }^{18}$ Germany had the second highest productivity growth rate at $1.9 \%$, while Italy and Spain had the lowest at $0.5 \%$ and $0.0 \%$, respectively.

This has two important implications. The first is that with fixed nominal exchange rates, EZ member states with a lower productivity level - which is typically measured by real per capita gross domestic product (GDP) - will find themselves at a competitive disadvantage when it comes to intraEZ trade - and one that grows systematically over time. The second is that the low productivity EZ member states will help to pull down the value of the euro on the international currency markets compared with the DEM. In other words,

$16 \mathrm{https}: / /$ www.reuters.com/article/germany-economy-trade/germany-torun-worlds-largest-current-account-surplus-in-2019-ifo-idUSL5N2641DF. 17 Note, the Belgian and Luxembourg Franc are aggregated. Source: http://fx.sauder.ubc.ca/euro/.

18 Labour productivity is defined as real value added per working hour. Source: Table 1 of Steffen Elstner, Lars P. Feld, and Christoph M. Schmidt (2018) The German Productivity Paradox - Facts and Explanations, Ruhr Economic Papers \#767, RWI - Leibniz-Institut für Wirtschaftsforschung, Essen, Germany: ISSN 1864-4872; http://www.rwiessen.de/media/content/pages/publikationen/ruhr-economicpapers/rep_18_767.pdf. the introduction of the euro has completely distorted the market in traded goods and services (1) between EZ member states themselves and (2) between the EZ and the rest of the world (ROW). Germany - and to a lesser extent the Netherlands - has been the biggest beneficiary of both these distortions. Notwithstanding the high quality of German goods, this is equivalent to dumping its artificially low-priced goods on the markets of both other EU states and the ROW, especially the UK post-Brexit, which until Brexit was a convenient captive market because EU law required the UK to accept the EZ's structure and disregard any unfairness that arose as a consequence.

\subsection{The Distortions Caused by the Euro between EZ Member States.}

Fig. (1) shows how the undervaluation of the euro compared with the DEM and Dutch Guilder has benefitted Germany and the Netherlands in terms of intra-EU exports. ${ }^{19}$ The two countries have $23 \%$ and $11 \%$, respectively, of intra-EU exports. This compares with $21 \%$ and $4.9 \%$, respectively, of EU GDP. ${ }^{20,21}$ The Netherlands' share of intra-EU exports is

19 https://ec.europa.eu/eurostat/statistics-explained/index.php?title=IntraEU_trade_in_goods_-_main_features\&oldid $=452727$.

20 EU GDP, 2018. Source: Eurostat;

http://appsso.eurostat.ec.europa.eu/nui/submitViewTableAction.do; http://appsso.eurostat.ec.europa.eu/nui/setupDownloads.do. Note, that the Netherlands estimate of the share of intra-EU exports might be upward biased due to the Rotterdam effect: goods from EU member states exported via the port of Rotterdam will be recorded as Dutch exports. Also note that in 2018, the German share of intra-EU exports was only 2 percentages points above its share of EU GDP. It might be expected to be higher, given the German productivity growth rate in Table 2 . However, Germany has, like many other developed countries, experienced a fall in productivity 


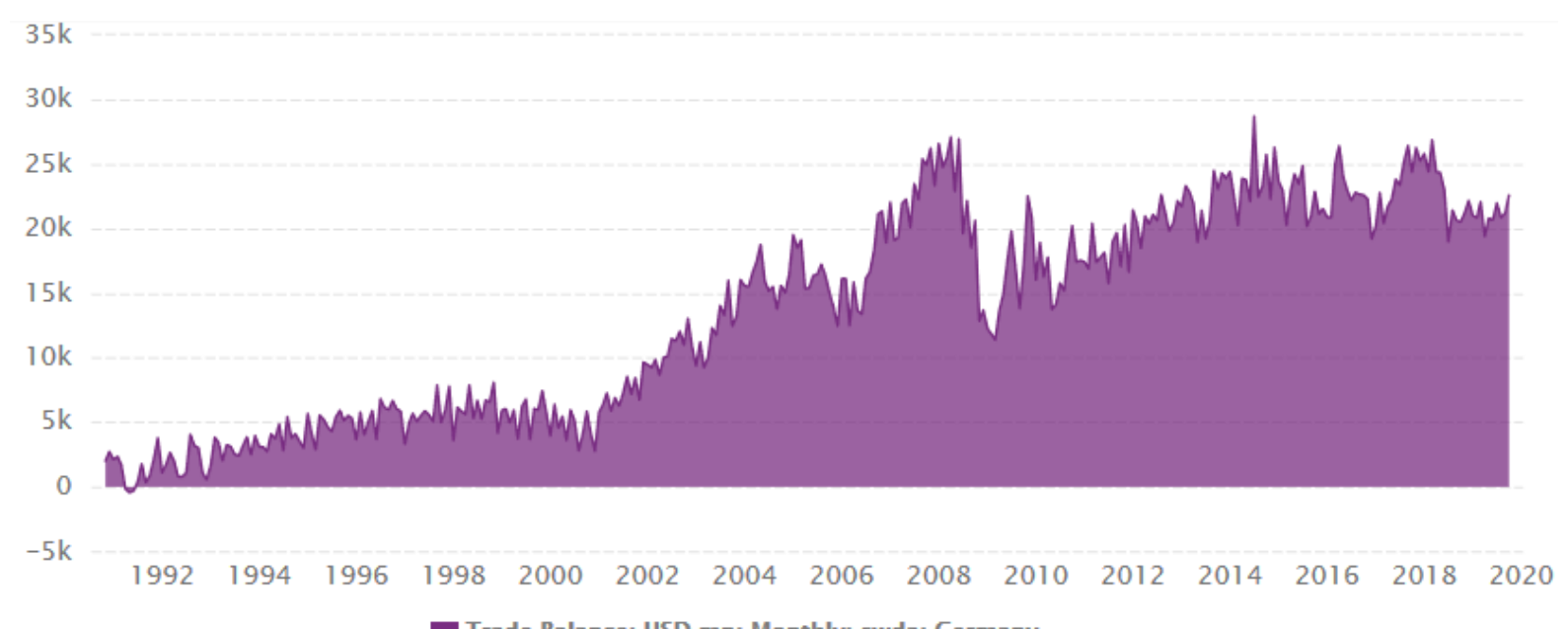

Trade Balance: USD mn: Monthly: swda: Germany

Fig. (2). Germany's trade balance with the rest of the world between November 1990 and November 2019.

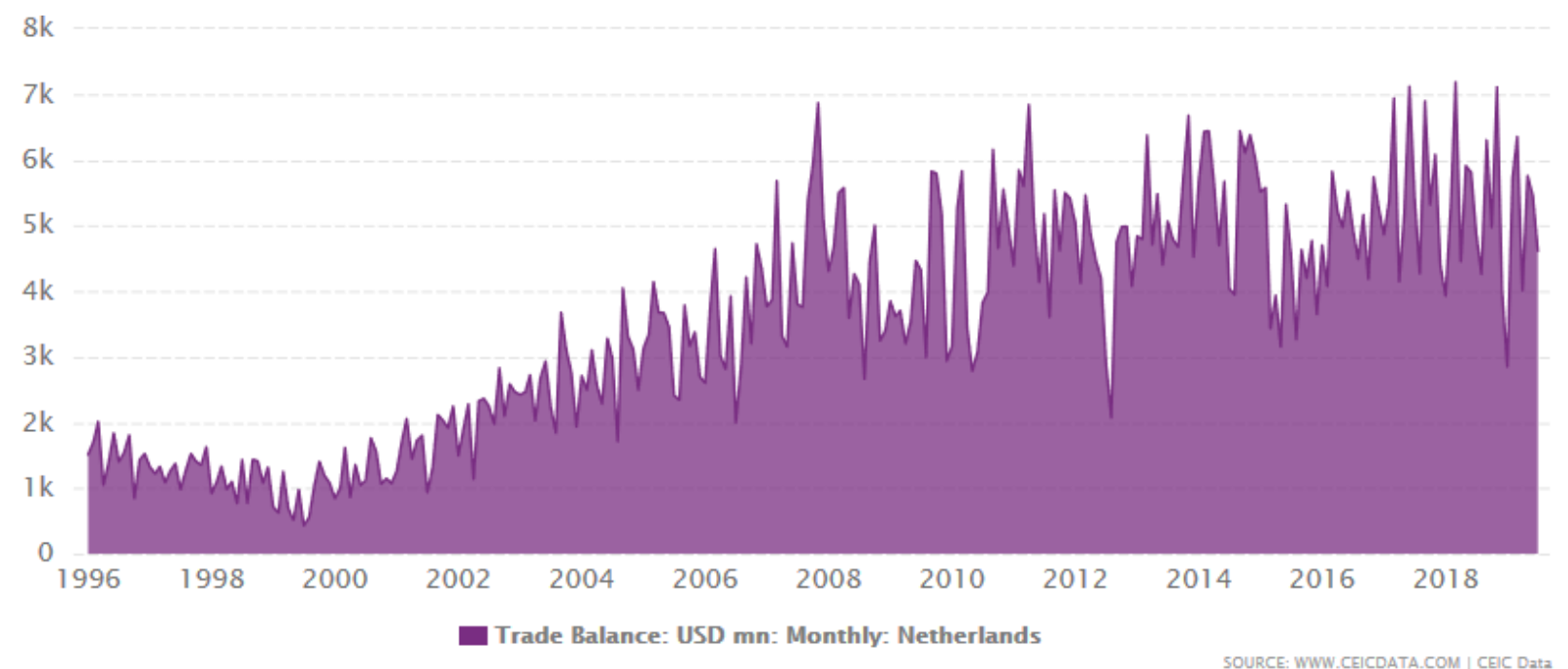

Fig. (3). The Netherlands' trade balance with the rest of the world between January 1996 and November 2019.

larger than that of France, Italy and Spain which constitute $14.1 \%, 11.1 \%$ and $7.6 \%$, respectively, of EU GDP.

Fig. (2) shows Germany's trade surplus between November 1990 and November 2019. ${ }^{22}$ During this period, Germany has always run a trade surplus, except briefly around the time of reunification. What is striking is the significant increase in the surplus since the introduction of the euro in 1999. This can be explained, in part, by Germany joining the euro at a very favourable conversion rate for the DEM. ${ }^{23}$ With floating exchange rates, countries with trade surpluses normally experience an increase in their nominal exchange rate which helps to reduce the surplus. This cannot happen in a fixed

growth in recent years, as explained in Steffen Elstner, Lars P. Feld, and Christoph M. Schmidt (op cit), which has had the effect of bringing down the German share of intra-EU exports.

21 Also note the high UK share of intra-EU exports. This, of course, is swamped by the size of intra-EU imports. For example, in 2018, the UK exported $£ 291$ bn of goods and services to the EU, but imported $£ 357 \mathrm{bn}$ (https://researchbriefings.files.parliament.uk/documents/CBP-7851/CBP7851.pdf).

22 https://www.ceicdata.com/en/indicator/germany/trade-balance.

23 We provide additional explanations for Germany's trade surplus below. exchange rate regime like the EZ. Of course, the size of Germany's trade surplus will help to drive up the relative international value of the euro, but by no means as much as the DEM would have risen in the same circumstances.

Fig. (3) shows the Netherlands' trade surplus between January 1996 and November $2019 .{ }^{24}$ There is a similar pattern as in the case of Germany, although it is more volatile. The explanation is the same.

Fig. (4) shows Italy's trade balance between January 1993 and November $2019 .{ }^{25}$ Prior to joining the euro in 1999, Italy had a trade surplus. But between 1999 and 2012, it mostly ran a trade deficit. This was because Italy joined the euro at an uncompetitively high conversion rate against the lira, leading to a fall in its exports relative to its imports. The reduction in exports was sufficient to lower the Italian economic growth rate to zero - and it has remained close to zero ever since. In other words, the Italian economy has barely grown in the last 20 years. This, in turn, explains why there

24 https://www.ceicdata.com/en/indicator/netherlands/trade-balance. $25 \mathrm{https}: / / \mathrm{www} . c e i c d a t a . c o m /$ en/indicator/italy/trade-balance. 


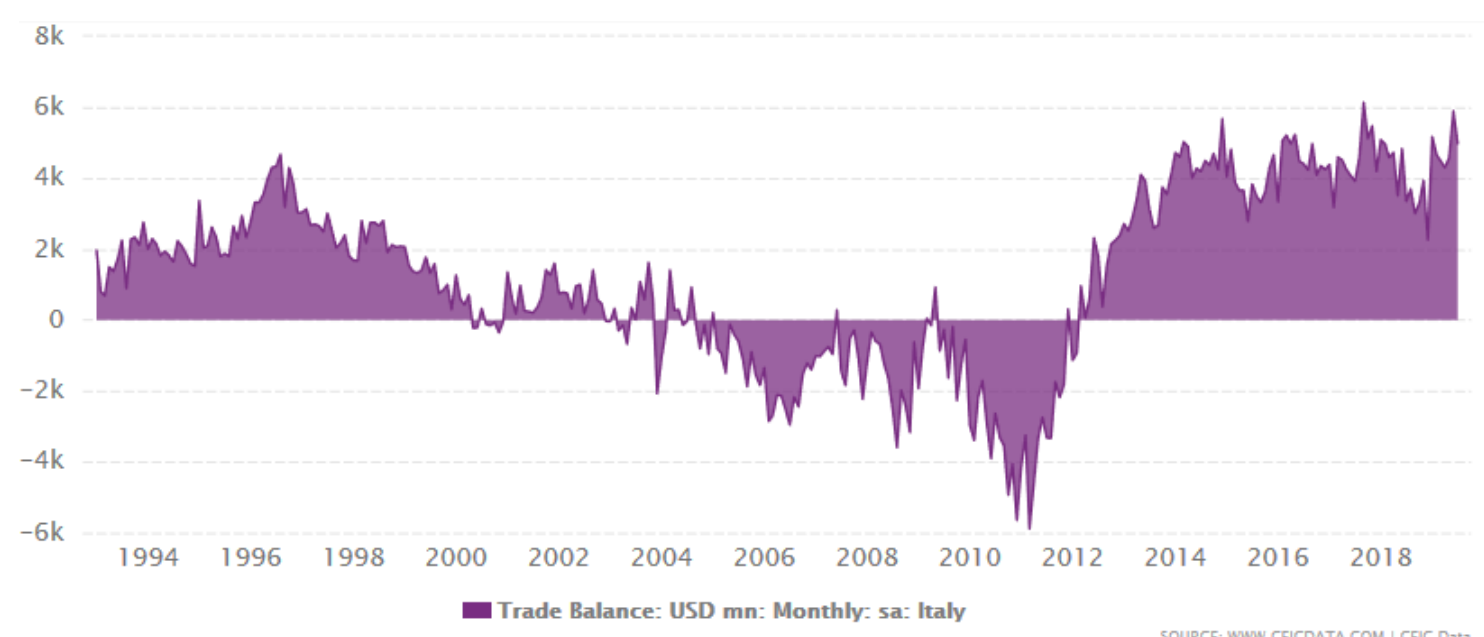

Fig. (4). Italy's trade balance with the rest of the world between January 1993 and November 2019.

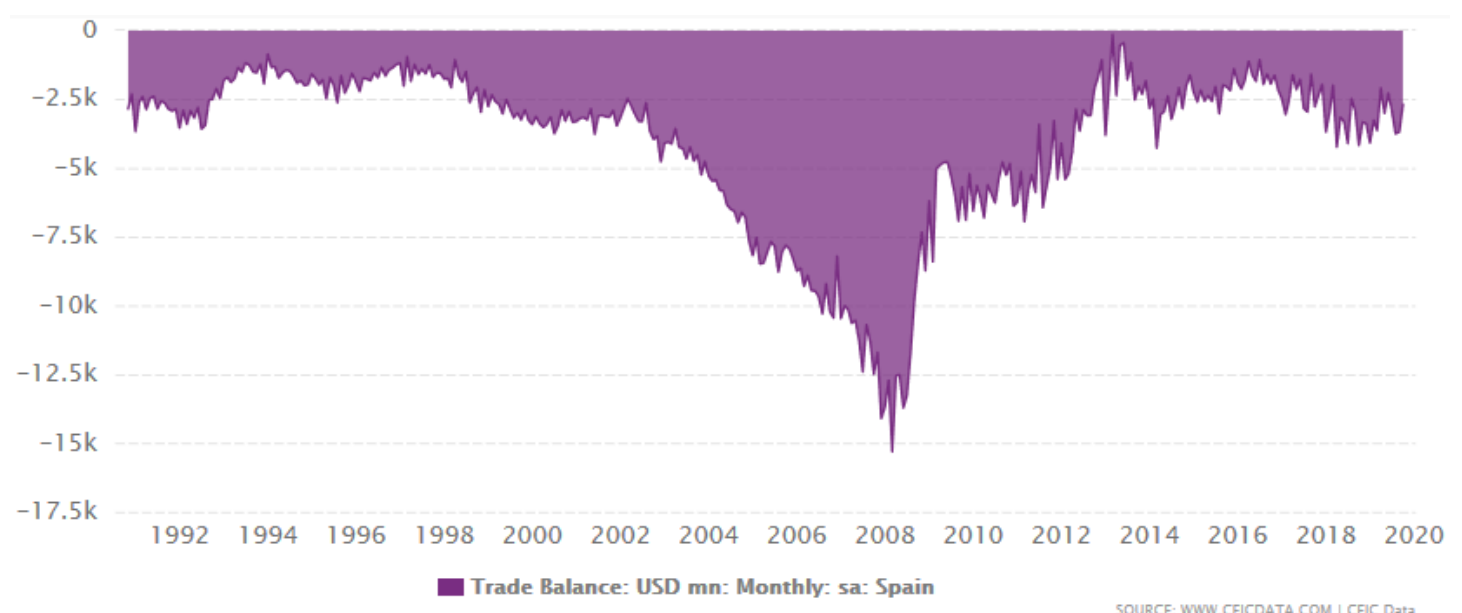

Fig. (5). Spain trade balance with the rest of the world between January 1990 and November 2019.

was a trade surplus after 2012. The economy was so depressed that imports fell by more than exports to such an extent that a trade surplus returned. But the reason for the trade surplus in Italy's case is very different from that explaining Germany's surplus. In Italy's case, it is mainly the result of weak domestic demand for imported goods. In Germany's case, it is the result of strong international demand for its exports.

Fig. (5) shows Spain's trade balance between January 1990 and November 2019. ${ }^{26}$ Unlike Italy, Spain has always had a trade deficit. Nevertheless, once we control for this, the experiences of the two Mediterranean economies have been very similar after they joined the euro. The Spain's trade deficit worsened considerably after joining the euro before recovering to pre-euro levels following the 2007-08 financial crisis. The reason is the same as in the case of Italy. Spain joined the euro at too high a conversion rate against the peseta. This reduced exports which, in turn reduced economic growth, via a negative multiplier effect. The financial crisis was followed by the Great Recession of 2008-12 which reduced the demand for imports and, perversely, improved the trade deficit. The same effect is there as in Fig. (4) for Italy.

26 https://www.ceicdata.com/en/indicator/spain/trade-balance.
Fig. (6) shows the TARGET2 27 balances for EZ member states between May 2001 and May 2021. ${ }^{28}$ In May 2021, Germany's credit balance was $€ 1,080 \mathrm{bn}$, while the debit balances for Italy and Spain were $€ 493$ bn and $€ 499$ bn, respectively. This is a direct consequence of the trade distortions caused by having a fixed exchange rate in the EZ, together with capital flight from Italy and Spain to Germany following the financial crisis.

TARGET2 was established to process cross-border payments within the EZ. These payments are ultimately for privatesector end-users, be they financial institutions, corporates or individuals. TARGET2 has the effect of converting privatesector cross-border liabilities into sovereign cross-border liabilities of EZ member states which are then treated by EU

27 TARGET2 is the high-value real-time gross settlement payment system for the euro, comprising the national high-value payment systems of the 19 Eurozone member states, the euro-denominated high-value payment systems in five non-Eurozone EU member states, and the arrangements between TARGET2-participating central banks and the ECB to make cross-border payments. All business in euros contracted with Eurosystem members must be settled through TARGET2, and it also carries the main financial markets business between financial institutions, as well as the settlements of balances in other Financial Markets Infrastructures.

28 http://www.eurocrisismonitor.com/. 


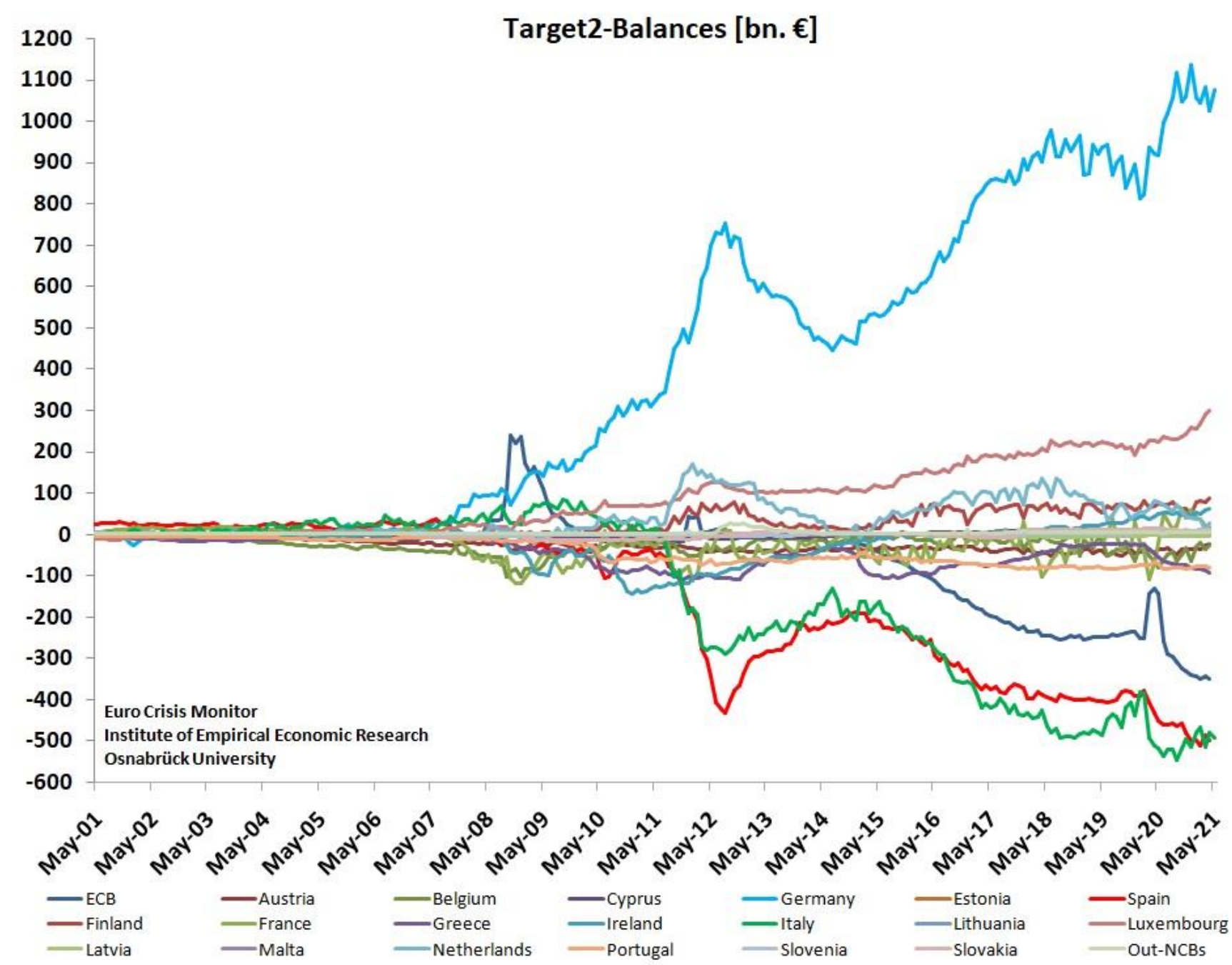

Fig. (6). TARGET2 balances for Eurozone member states, May 2001- May 2021.

law as risk-free. To illustrate, suppose an Italian company imports machinery from a German company and finances this with a loan from its Italian bank. The Italian bank debits the loan account and makes a payment into the German company's German bank. This, in turn, leads to a TARGET2 debit for the Banca d'Italia and a TARGET2 credit for the Bundesbank. The balances between the Banca d'Italia and the Bundesbank are not settled, but are rather novated to the ECB at end-of-day, before being reversed back on to their original accounts at the start of the following day. The Banca d'Italia would retain either a deposit of the Bundesbank on its books or an overdraft on its own account at the Bundesbank. Either way, the private Italian company's loan has become a liability of the Italian government to the German government - and hence should be counted as part of Italy's national debt (although EU accounting practice does not do this). ${ }^{29}$

29 TARGET2 has become a mechanism for bailing out the euro. Eurozone member states are able to borrow through the TARGET2 system without paying interest and without having to repay the loan. This should be regarded as a form of subsidy, mainly from Germany, to compensate for the euro's incomplete structure. See David Blake (2018) Target2: The Silent Bailout
Fig. (6) shows that the system was broadly in balance between the launch of the euro and the Global Financial Crisis (GFC). The Great Recession that followed - which was much worse in Italy and Spain than in Germany - led to a loss of confidence in the Italian and Spanish banking sectors and investors and depositors moved their funds to German, Luxembourg, and Dutch banks through TARGET2. This is clearly visible in the Figure. Also visible is the effect of the European Sovereign Debt Crisis which peaked between 2010 and $2012 .^{30}$ It began in 2008 with the collapse of Iceland's banking industry and then spread to Portugal, Italy, Ireland, Greece, and Spain in 2009. The governments in these EZ countries had to borrow heavily to bail out their banks. Yields on the government bonds rose and the markets closed on them to further borrowing. Fearing financial contagion and the collapse of the euro, the EU and the IMF provided the necessary loans. But the capital flight from Italy and Spain during the period is transparent.

System that Keeps the Euro Afloat, SSRN, 22 May; https://papers.ssrn.com/sol3/papers.cfm?abstract_id=3182995. $30 \mathrm{https}: / / \mathrm{www}$. investopedia.com/terms/e/european-sovereign-debtcrisis.asp. 
Table 3. Ratio of Purchasing Power Parity to Actual Exchange Rates for Selected Countries, 1999-2019.

\begin{tabular}{|c|c|c|c|c|c|}
\hline Year & Eurozone & UK & Japan & Canada & China \\
\hline 2000 & 0.797 & 1.066 & 1.436 & 0.826 & 0.327 \\
\hline 2001 & 0.770 & 1.000 & 1.232 & 0.788 & 0.326 \\
\hline 2002 & 0.806 & 1.034 & 1.147 & 0.783 & 0.323 \\
\hline 2004 & 1.066 & 1.261 & 1.242 & 0.948 & 0.339 \\
\hline 2005 & 1.061 & 1.287 & 1.175 & 1.002 & 0.345 \\
\hline 2006 & 1.039 & 1.283 & 1.071 & 1.063 & 0.358 \\
\hline 2007 & 1.125 & 1.421 & 1.022 & 1.129 & 0.393 \\
\hline 2010 & 1.050 & 1.084 & 1.272 & 1.186 & 0.489 \\
\hline 2011 & 1.086 & 1.131 & 1.346 & 1.253 & 0.543 \\
\hline 2012 & 0.995 & 1.108 & 1.307 & 1.245 & 0.558 \\
\hline 2013 & 1.003 & 1.087 & 1.038 & 1.188 & 0.570 \\
\hline 2014 & 0.999 & 1.149 & 0.973 & 1.114 & 0.569 \\
\hline 2015 & 0.838 & 1.058 & 0.855 & 0.976 & 0.556 \\
\hline 2016 & 0.808 & 0.930 & 0.970 & 0.910 & 0.521 \\
\hline
\end{tabular}

\subsection{The Distortions Caused by the Euro between the EZ and the Rest of the World}

The euro is undervalued internationally on a purchasing power parity (PPP) basis, and has been for most of the time since it was introduced - although not by as much as the RMB. The OECD defines purchasing power parities by reference to the rates of currency conversion that equalise the purchasing power of different currencies, by eliminating the differences in price levels between countries. The basket of goods and services priced is a sample of all those that are part of final expenditures: final consumption of households and government, fixed capital formation, and net exports. ${ }^{31,32}$

$31 \mathrm{https}: / /$ stats.oecd.org/glossary/detail.asp?ID=2205

32 While a comparison of purchasing power parities between currencies is a useful indicator of their relative valuation, it is important to recognise that PPP prices cover the whole economy, much of which is not traded interna-
Table 3 shows the ratio of PPP to actual exchange rates in the EZ, the UK, Japan, Canada and China between 1999 and 2019. Figure 7 shows a graph of this ratio for the EZ, the UK and China over the same period Since nominal exchange rates are measured in terms of national currency units per US dollar, a ratio below unity indicates undervaluation of the actual currency relative to its PPP value. To illustrate, in 1999, the ratio was 0.932 in the EZ: this is found by taking the ratio of the PPP exchange rate in 1999 (0.874) to the actual exchange rate in the same year (0.938). This means that, absent transactions costs, it would be possible to buy a good in the EZ for $€ 0.874$, sell it in the US for $\$ 1$, exchange the proceeds back into euros at the actual exchange rate of 0.938 , and make a profit of $6.8 \%$ (i.e., 1 minus 0.932 , the ratio of the PPP and actual exchange rates). There would be

tionally. There are also other influences on currency values, including trade in services and capital flows. 


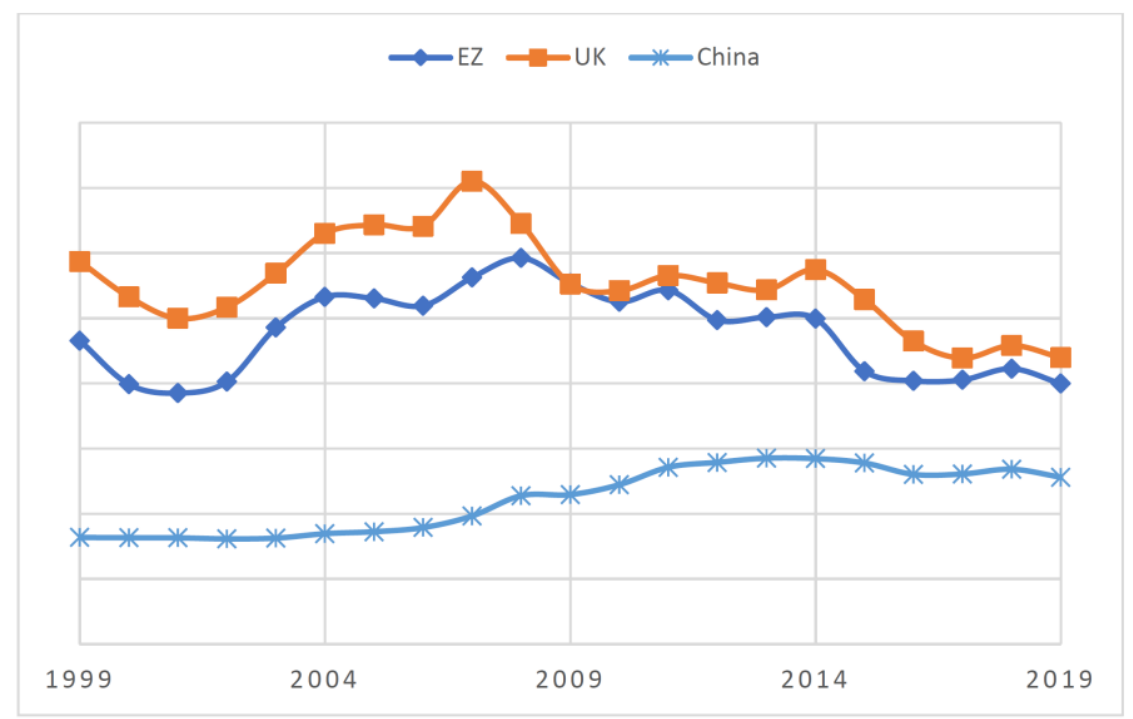

Fig. (7). Ratio of purchasing power parity to actual exchange rates for the Eurozone, the UK and China, 1999-2019.

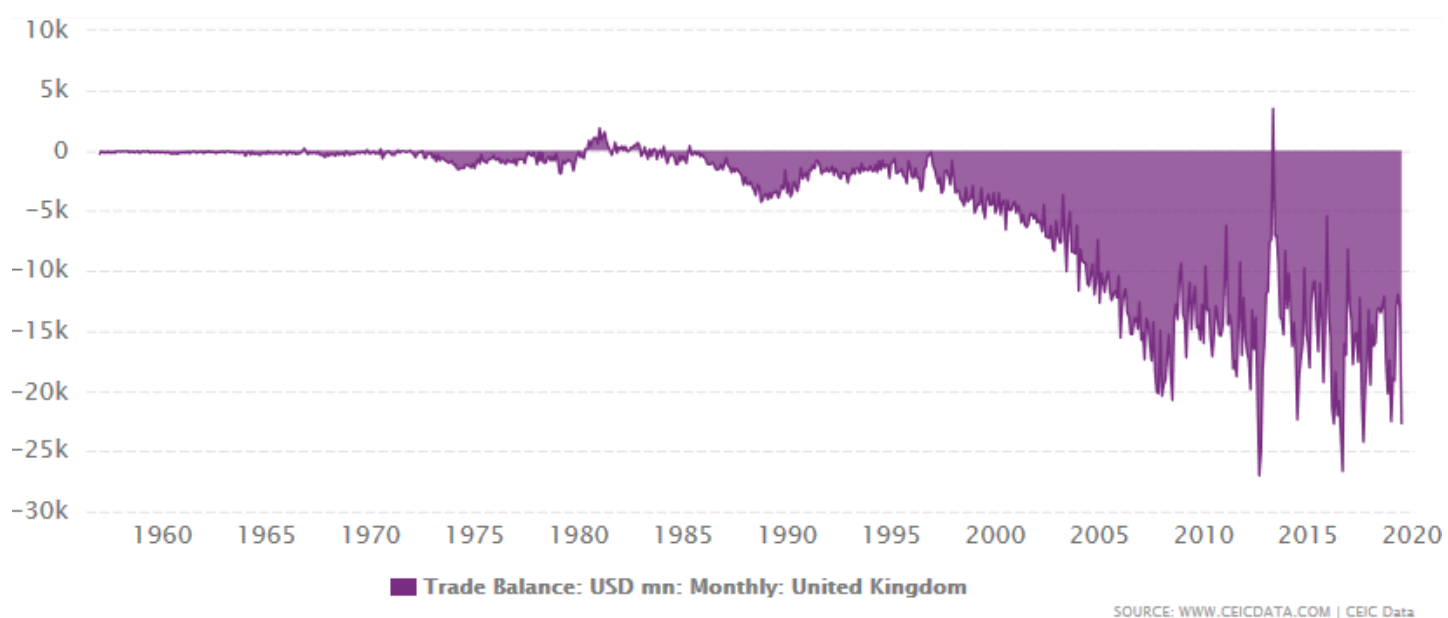

Fig. (8). UK trade balance with the rest of the world between January 1957 and November 2019

no profit if the actual exchange rate equalled its PPP value of 0.874. The Table shows that, except for the period around the GFC, the euro has been undervalued on a PPP basis, by an average of $4.3 \%$. Sterling and the Japanese yen, by contrast, were overvalued over the period by an average of $10.9 \%$ and $13.8 \%$, respectively. ${ }^{33}$ Sterling has been undervalued on a PPP basis only since 2016, and that is due to the market's overreaction to the Brexit Referendum result. Not surprisingly, given its geographical proximity to the US, the Canadian dollar has traded on average at its PPP value over the period. Only the RMB has traded at a lower value on a PPP-adjusted basis than the euro, averaging 0.445 - an un-

33 The main reason for sterling's overvaluation lies in capital account activities. There is a high demand for sterling coming from (1) foreign direct investors, including portfolio and real estate investors, buying UK equities, government bonds and property (there are few other politically stable countries that allow such unrestricted access) and (2) the repatriation of dividends, etc, from the UK's relatively large holding of overseas investments, in particular, by institutional investors, such as pension funds. See, e.g., Ashoka Mody (2016) Don't believe what you've read: the plummeting pound sterling is good news for Britain, The Independent, 10 October; https://www.independent.co.uk/news/business/comment/why-theplummeting-pound-sterling-is-good-news-for-britain-a7353846.html. dervaluation of $55 \%$. Fig. (7) shows that the undervaluation of the euro is the greatest it has ever been except for 2001 . This provides very powerful support for the argument made above that the way that the euro was structured and valued at inception has allowed the euro to remain undervalued ever since.

The euro's relative undervaluation is increased by virtue of EZ member states avoiding the full costs of operating a single currency. The EU is a single trading area - a customs union - under World Trade Organisation (WTO) rules. The 27 member states of the EU are accorded this recognition because they have a common internal trading area - the single market - and a common external tariff schedule. Within that trading area, some states have individual currencies, in the normal way. There is also the EZ with 19 members of the EU that use a single currency, the euro. However, as discussed above, the EZ comprises sub-sovereign states with no sovereign state sitting above them. This arrangement gives those states the economic benefits of a structurally undervalued currency, whilst they avoid the costs of joint-and-several liability that is both intrinsic to a proper currency zone and a key feature of the sovereign entity that sits at the top of a genuinely federal collection of states. This set-up cannot 
have been envisioned to be legitimate under WTO rules which were conceived before the euro existed, since it is a structural lacuna which has resulted in a persistent trade advantage. ${ }^{34}$

\subsection{The Distortions Caused by the Euro Between the EZ and the UK}

Fig. (8) shows the UK's trade balance between January 1957 and November 2019. ${ }^{35}$ It has almost always run a deficit over the period, but the deficit worsened considerably after the introduction of the euro.

Table 4. UK Trade with the EU (Goods and Services), 19992019.

\begin{tabular}{|c|c|c|c|c|c|}
\hline & \multicolumn{2}{|c|}{ Exports } & \multicolumn{2}{|c|}{ Imports } & \multirow{2}{*}{$\begin{array}{c}\text { Balance } \\
\mathfrak{E} \\
\text { Billions }\end{array}$} \\
\hline & $\begin{array}{c}£ \\
\text { Billions }\end{array}$ & $\%$ of Total & $\begin{array}{c}£ \\
\text { Billions }\end{array}$ & $\%$ of Total & \\
\hline 1999 & 133.9 & 53.8 & 147.0 & 55.9 & -13.1 \\
\hline 2000 & 146.8 & 53.2 & 157.3 & 53.3 & -10.4 \\
\hline 2001 & 153.2 & 53.7 & 171.1 & 55.1 & -17.9 \\
\hline 2002 & 155.1 & 54.0 & 184.5 & 58.1 & -29.4 \\
\hline 2003 & 156.5 & 52.2 & 189.2 & 57.7 & -32.7 \\
\hline 2004 & 160.7 & 51.3 & 196.4 & 56.6 & -35.7 \\
\hline 2005 & 178.6 & 51.2 & 214.9 & 56.2 & -36.3 \\
\hline 2006 & 215.6 & 53.9 & 243.7 & 56.7 & -28.1 \\
\hline 2007 & 196.5 & 50.2 & 229.4 & 54.4 & -32.9 \\
\hline 2008 & 213.6 & 49.8 & 244.2 & 52.7 & -30.5 \\
\hline 2009 & 196.9 & 48.3 & 225.8 & 52.1 & -28.9 \\
\hline 2010 & 217.7 & 48.1 & 247.8 & 51.1 & -30.1 \\
\hline 2011 & 243.3 & 47.7 & 265.7 & 50.6 & -22.4 \\
\hline 2012 & 233.8 & 45.6 & 271.8 & 51.0 & -37.9 \\
\hline 2013 & 235.8 & 44.2 & 287.5 & 51.7 & -51.7 \\
\hline 2014 & 237.6 & 44.8 & 293.0 & 52.6 & -55.5 \\
\hline 2015 & 224.5 & 42.4 & 294.0 & 52.8 & -69.4 \\
\hline 2016 & 248.0 & 43.7 & 318.2 & 53.0 & -70.2 \\
\hline 2017 & 280.9 & 44.7 & 345.4 & 52.8 & -64.5 \\
\hline 2018 & 291.0 & 45.3 & 357.4 & 52.6 & -66.4 \\
\hline 2019 & 294.3 & 42.6 & 373.5 & 51.8 & -79.2 \\
\hline $\begin{array}{l}\text { Source } \\
\text { Numb } \\
\text { https:// } \\
7851 . p\end{array}$ & $\begin{array}{l}\text { atistics or } \\
851,10 \mathrm{~N} \\
\text { earchbrief }\end{array}$ & $\begin{array}{l}K \text {-EU Trade, } \\
\text { ember } 2020 \\
\text { s.files.parlia }\end{array}$ & ouse of C & Imons Briefin & $\begin{array}{l}\text { Paper, } \\
\text { /CBP- }\end{array}$ \\
\hline
\end{tabular}

34 See Barnabas Reynolds, David Blake, and Robert Lyddon (2020) Managing Euro Risk, Politeia, 27 February.

35 https://www.ceicdata.com/en/indicator/united-kingdom/trade-balance.
Table 4 shows how the UK trade deficit with the EU has systematically deteriorated over the period of the euro's existence.

Table 5 shows the compound annual growth rate (CAGR) of UK goods exports to the 12 members of the EZ (EZ12) from 1999 to 2018. Column 1 shows the real CAGR (inflation adjusted to $2016 \mathrm{GDP}$ ) of UK exports to the 12 was $0.62 \% .^{36}$ Six of these $12 \mathrm{EZ}$ states countries are underlined, because UK goods exports to them have declined in real terms over these two decades rather than grown. The third column shows that the cumulative trade deficit was $£ 687 \mathrm{bn}$.

Table 5. Real Growth of UK Exports of Goods to the 12 Original Members of the Eurozone, 1999-2018, and Cumulative Trade Balance.

\begin{tabular}{|c|c|c|c|}
\hline Trade Partner & $\begin{array}{l}\text { CAGR UK } \\
\text { Goods } \\
\text { Exports \% }\end{array}$ & $\begin{array}{c}\text { Divergence from } \\
\text { CAGR of Part- } \\
\text { ner's GDP } \\
\text { (\% Points) }\end{array}$ & $\begin{array}{c}\text { 20-Year } \\
\text { Trade } \\
\text { Balance £bns }\end{array}$ \\
\hline Austria & 0.67 & $\underline{-0.98}$ & $\underline{-24.75}$ \\
\hline Belgium & 0.57 & $\underline{-0.99}$ & $\underline{-85.60}$ \\
\hline Finland & $\underline{-2.09}$ & $\underline{-3.68}$ & $\underline{-26.35}$ \\
\hline France & $\underline{-0.05}$ & $\underline{-1.46}$ & $\underline{-32.66}$ \\
\hline Germany & 1.06 & $\underline{-0.32}$ & $\underline{-378.28}$ \\
\hline Greece & $\underline{-2.30}$ & $\underline{-2.53}$ & 14.46 \\
\hline Ireland & 1.53 & $\underline{-3.26}$ & 133.63 \\
\hline Italy & $\underline{-0.37}$ & $\underline{-0.76}$ & $\underline{-87.50}$ \\
\hline Luxemburg & 0.46 & $\underline{-2.47}$ & $\underline{-7.81}$ \\
\hline Netherlands & 1.56 & 0.03 & $\underline{-137.99}$ \\
\hline Portugal & $\underline{-2.82}$ & $\underline{-3.53}$ & $\underline{-8.58}$ \\
\hline Spain & $\underline{-0.26}$ & $\underline{-2.12}$ & $\underline{-44.42}$ \\
\hline EZ12 & 0.62 & $\underline{-0.82}$ & $\underline{-686.85}$ \\
\hline \multicolumn{4}{|l|}{ Memo: } \\
\hline EU27 & 0.78 & -2.59 & $\underline{-868.79}$ \\
\hline
\end{tabular}

Sources: https://www.ons.gov.uk/economy/nationalaccounts/ balanceofpayments/datasets/uktradeallcountriesseasonallyadjusted with export deflator

https://www.ons.gov.uk/economy/grossdomesticproductgdp/ timeseries/ybfw/ukea\#thertimeseries

Michael Burrage and Phil Radford (2020) WTO vs the EU: An Assessment of the Relative Merits of the UK's Trade Relationships 1999-2018, Civitas, June; https://www.civitas.org.uk/publications/wto-vs-the-eu/.

UK goods exports to the 14 leading countries that the UK trades with on WTO terms (denoted WTO14) - meaning in the absence of a preferential trade agreement, and hence in-

36 Had we assumed that the present 27 EU members had all been single market members over the same period, the CAGR of UK goods exports to all 27 would have been slightly higher at $0.78 \%$. 
volving the payment of tariffs - had a CAGR of 3.58\%, ${ }^{37}$ compared with $0.62 \%$ for the EZ12. So they grew nearly six times faster between 1999 and 2018 than trade with the EZ12, despite the higher tariffs.

One explanation frequently offered for why the UK's trade with the ROW has grown at a faster rate than its trade with the EU and, in particular, EZ countries is that the ROW's economies have grown at a faster rate over the last 20 years. The aggregate CAGR of the GDP of the WTO14 was 3.53\% between 1999 and $2018 .^{38}$ This is indeed significantly higher than the 1.44\% GDP CAGR of the EZ12. ${ }^{39}$

However, Column 2 of Table 5 shows the CAGRs of UK exports to the EZ12 compared with the CAGR of their GDP. The growth of UK goods exports to the EZ12 over these two decades was below the growth of the GDP of them all, except for the Netherlands. ${ }^{40}$ Something more than the differential growth rates in the economies of these two groups of countries must be involved. It cannot be related to the quality of the goods offered for sale or indeed the UK's marketing abilities within the EU single market - since neither has impeded UK export growth outside the EZ. A key explanation must lie in the euro and its systematic undervaluation compared with sterling - which makes UK exports to the EZ look expensive.

Table 3 shows that the average undervaluation of the euro against the US dollar over the period 1999-2019 was 4.3\% (1 minus 0.957), while the average overvaluation of sterling against the US dollar was $10.9 \%$ (1.109 minus 1). This means that the euro was undervalued against sterling by $15.2 \%$ (4.3 plus 10.9). If we disregard the period after 2016 when sterling fell as a market overreaction to the Brexit Referendum, then sterling was overvalued against the US dollar over the period $1999-2015$ by $15.7 \%$, and hence the euro's undervaluation against sterling was $20 \%$.

Table 6. UK Trade with Non-EU Countries (Goods and Services), 1999-2019.

\begin{tabular}{|c|c|c|c|c|c|}
\hline & \multicolumn{2}{|c|}{ Exports } & \multicolumn{2}{|c|}{ Imports } & \multirow{2}{*}{$\begin{array}{c}\text { Balance } \\
\mathfrak{f} \\
\text { Billions }\end{array}$} \\
\hline & $\begin{array}{c}\mathfrak{f} \\
\text { Billions }\end{array}$ & $\%$ of Total & $\begin{array}{c}£ \\
\text { Billions }\end{array}$ & $\%$ of Total & \\
\hline 1999 & 114.9 & 46.2 & 116.2 & 44.1 & -1.3 \\
\hline 2000 & 129.2 & 46.8 & 137.8 & 46.7 & -8.6 \\
\hline 2001 & 132.1 & 46.3 & 139.3 & 44.9 & -7.2 \\
\hline 2002 & 131.9 & 46.0 & 133.2 & 41.9 & -1.3 \\
\hline 2003 & 143.5 & 47.8 & 138.5 & 42.3 & 5.0 \\
\hline 2004 & 152.4 & 48.7 & 150.3 & 43.4 & 2.1 \\
\hline
\end{tabular}

37 Table 2 of Michael Burrage and Phil Radford (2020) WTO vs the EU: An Assessment of the Relative Merits of the UK's Trade Relationships 1999-2018, Civitas, June; https://www.civitas.org.uk/publications/wto-vsthe-eu/.

38 https://data.worldbank.org/indicator/NY.GDP.MKTP.KD 2010.

39 And also higher than the $1.73 \%$ growth rate of the EU27.

40 This could be explained by the Rotterdam effect.

\begin{tabular}{|c|c|c|c|c|c|}
\hline 2005 & 170.1 & 48.8 & 167.3 & 43.8 & 2.8 \\
\hline 2006 & 184.1 & 46.1 & 186.3 & 43.3 & -2.2 \\
\hline 2007 & 194.7 & 48.9 & 192.5 & 45.6 & 2.2 \\
\hline 2008 & 215.5 & 50.2 & 219.1 & 47.3 & -3.7 \\
\hline 2009 & 211.5 & 51.7 & 207.2 & 47.9 & 4.0 \\
\hline 2010 & 235.2 & 51.9 & 237.2 & 48.9 & -1.9 \\
\hline 2011 & 266.3 & 52.3 & 258.9 & 49.4 & 7.4 \\
\hline 2012 & 279.5 & 54.4 & 261.6 & 49.0 & 17.9 \\
\hline 2013 & 298.1 & 55.8 & 269.0 & 48.3 & 28.9 \\
\hline 2014 & 293.1 & 55.2 & 263.6 & 47.4 & 29.5 \\
\hline 2015 & 305.5 & 57.6 & 262.6 & 47.2 & 42.9 \\
\hline 2016 & 319.5 & 56.3 & 281.6 & 47.0 & 37.9 \\
\hline 2017 & 348.2 & 55.3 & 308.8 & 47.2 & 39.4 \\
\hline 2018 & 351.2 & 54.7 & 322.6 & 47.4 & 28.7 \\
\hline 2019 & 396.5 & 57.4 & 347.8 & 48.2 & 48.7 \\
\hline $\begin{array}{l}\text { Source: Statistics on UK-EU Trade, House of Commons Briefing Paper, } \\
\text { Number 7851, } 10 \text { November 2020; } \\
\text { https://researchbriefings.files.parliament.uk/documents/CBP-7851/CBP- } \\
7851 . p d f\end{array}$ & & & & \\
\hline
\end{tabular}

Table 6 shows that the UK mostly has a trade surplus with the countries outside the EU. The UK trades on WTO terms with some key non-EU countries, including the US (the UK's biggest single trading partner), China (the UK's third biggest trading partner after Germany), Japan, Canada, Australia, India and Brazil. Despite this, UK trade grew at a faster rate than with the EU where trade is supposed to be 'frictionless'.

In 2019, the UK ratio of exports to imports with the EU27 was only $79 \% .{ }^{41}$ Figure 9 shows the UK goods trade deficit with EU member states in $2019 .{ }^{42}$ Particularly noteworthy is the scale of the deficit with Germany, mainly in automobiles. Even allowing for potential quality differences between British and German cars, a key explanation for the size of this deficit is again the undervaluation of the euro. While the UK maintains the close economic ties with the EU27 that the EU wants, ${ }^{43}$ the UK will remain a captive market for German and other EZ member goods and will be unable to address the structural disadvantage which it finds itself in - such as the systematic decline in manufacturing as a share of GDP,

$41 \mathrm{https}: / /$ ec.europa.eu/eurostat/statistics-explained/index.php?title=IntraEU_trade_in_goods_-_main_features\&oldid=452727\#IntraEU_trade_in_goods_balance.

$42 \mathrm{https} / / /$ researchbriefings.files.parliament.uk/documents/CBP-7851/CBP7851.pdf.

43 These close economic ties are baked into the EU-UK Trade and Cooperation Agreement introduced on 1 January 2021;

https://assets.publishing.service.gov.uk/government/uploads/system/uploads lattachment data/

file/948119/EU-UK_Trade_and_Cooperation_Agreement_24.12.2020.pdf 
see Fig. (10). ${ }^{44}$ Figure 11 shows the much smaller UK services trade surplus with EU member states in 2019. ${ }^{45}$

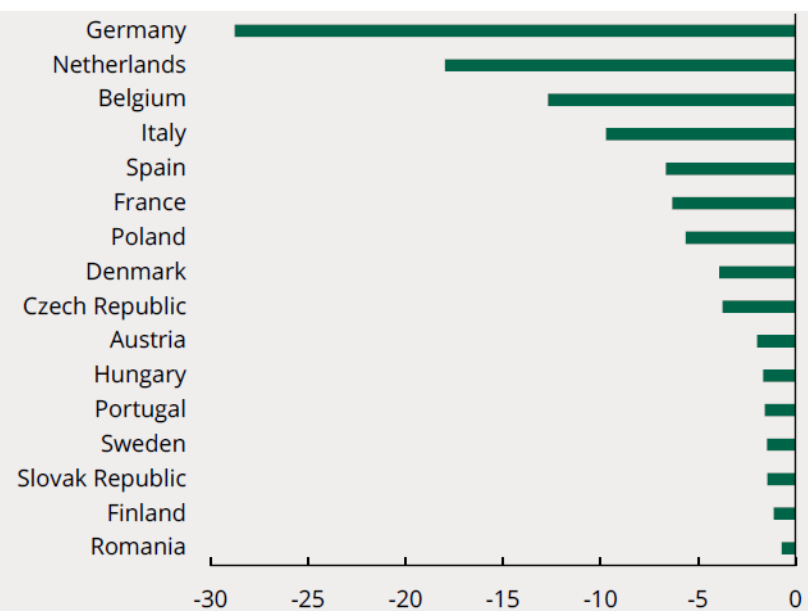

Fig. (9). UK-EU trade deficit in goods, 2019 (£bn).

Source: Statistics on UK-EU Trade, House of Commons Briefing Paper, Number 7851, 10 November 2020;

https://researchbriefings.files.parliament.uk/documents/CBP-

7851/CBP-7851.pdf

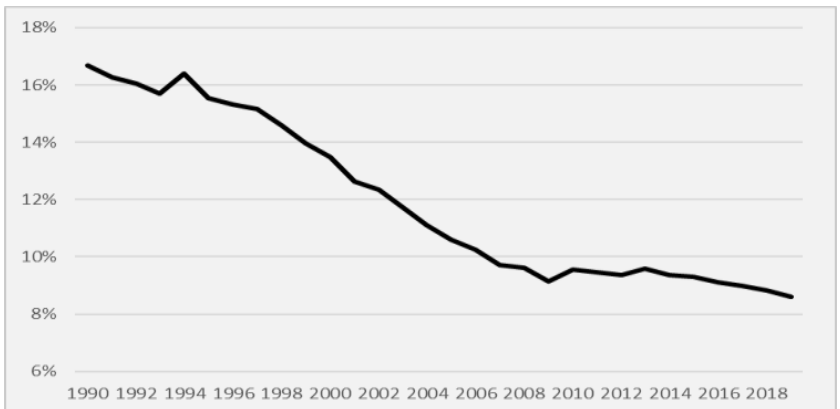

Fig. (10). Manufacturing, United Kingdom, $1990-2019$ (\% of GDP).

Source:

www.macrotrends.net/countries/GBR/united-

kingdom/manufacturing-output

We can conclude that the increase in the total UK trade deficit in Figure 8 is due almost exclusively to the increase in the trade deficit with the EZ and that this is, in turn, due (principally) to the persistent undervaluation of the euro. This has allowed EZ member states - and especially Germany and the Netherlands - to dump their products onto the UK market. The EZ is also able to dump onto global markets for the same reason.

This problem is recognised in Germany, although not as a problem of dumping. For example, Gabriel Felbermayr, the

44 It is fair to say that part of the declining manufacturing share in Figure 10 is due to the overvaluation of sterling which has made it very difficult for UK manufacturers to compete against much cheaper Chinese imports. See: John Mann (2021), A post-Brexit economy needs a lower sterling exchange rate, Briefings for Britain, 4 April, https://www.briefingsforbritain.co.uk/apost-brexit-economy-needs-a-lower-sterling-exchange-rate $45 \mathrm{https}$ ///researchbriefings.files.parliament.uk/documents/CBP-7851/CBP7851.pdf.

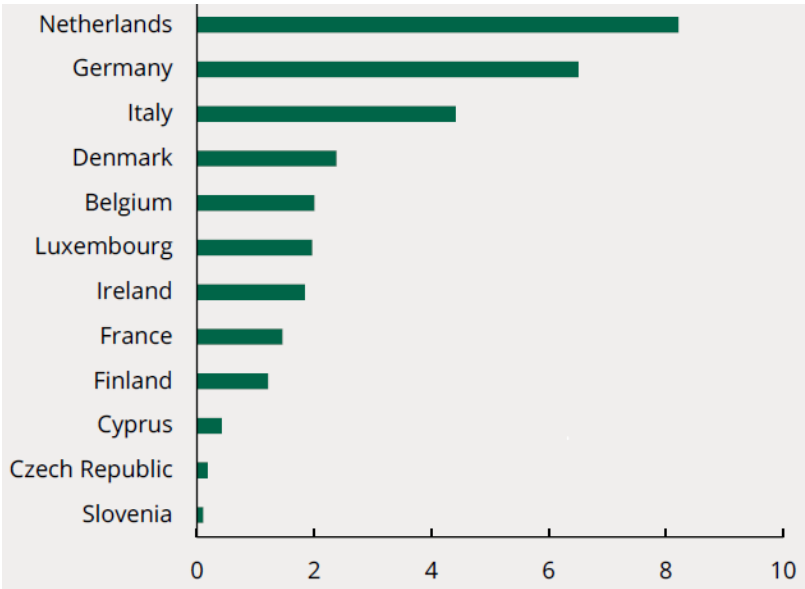

Fig. (11).UK-EU trade surplus in services, 2019 (£bn)

Source: Statistics on UK-EU Trade, House of Commons Briefing Paper, Number 7851, 10 November 2020;

https://researchbriefings.files.parliament.uk/documents/CBP7851/CBP-7851.pdf

director of the Munich-based ifo Center for International Economics has recently said: ${ }^{46}$

Germany exporting more than it imports is becoming a big problem for its economy. [The trade surplus] is turning out to be an increasing issue, not just with the U.S. but with other trade partners as well, and also within the European Union. The surplus is becoming toxic, and also within Germany many argue now that we need to do something about it with the purpose of lowering it. It turns out to be a liability rather than an asset.

Germany's export-orientated, manufacturing economy and its resulting trade surplus - the value of its exports exceeding that of its imports - has long been a subject of criticism and Berlin has been pressured to encourage more domestic spending and boost imports. Trade surpluses are viewed as encouraging trade protectionism and worsening the economic problems of other countries.

\subsection{Explanations for the Euro's Persistent Undervalua- tion}

We have provided evidence above that the euro has been undervalued against sterling, in particular, on a PPP basis for the whole of its existence - see Fig. (7).

However, many economists would argue that within a common currency area, like the EZ, prices and wages should eventually equalise, removing internal trade imbalances, and, in an open global macroeconomy context, PPP should hold in the long run, i.e., there should be a long-run equilibrium in relative EZ prices to ROW prices (measured in a common currency), which should remove the relative undervaluation of the euro and, in turn, remove external trade imbalances in due course.

46 Holly Ellyatt (2018) Germany's massive trade surplus 'is becoming toxic,' Ifo director says, CNBC, 4 July; https://www.cnbc.com/2018/07/04/germanys-massive-trade-surplus-isbecoming-toxic-ifo-director-says.html. 
Nevertheless, persistent deviations of exchange rates from PPP levels have been noted by academic economists for some time. Early studies include Frenkel (1976), Kravis, Heston and Summers (1982) and Kravis and Lipsey $(1978,1982,1987,1988) .{ }^{47}$ Kravis, Heston and Summers (1982), for example, found that prices levels in some developing countries were one third of the US price level, so our estimate of the euro's undervaluation against sterling of between $15.2 \%$ and $20 \%$ is not out of line with historical evidence.

Kravis and Lipsey (1978) were amongst the earliest economists to suggest that long-term deviations from PPP implied that the exchange rate market is in disequilibrium. Economists tend not to like the idea that an economic system can be in a state of disequilibrium - at least on a permanent basis. This gave rise to a debate, essentially between Keynesians and monetarists, which, in turn, generated 'disequilibrium' and 'equilibrium' models of the exchange rate. One the one hand, economists like Dornbusch $(1976,1987)^{48}$ developed a disequilibrium model that could explain shortrun deviations from PPP but moved towards PPP in the longrun - which is not consistent with the facts. On the other hand, economists like Lucas $(1978)^{49}$ and Stockman $(1987)^{50}$ developed equilibrium models that allow for permanent departures from PPP, but do not explain short-run exchange rate dynamics.

So the economic literature is not clear on whether there can be long-run deviations from PPP, nor is it clear on how long it should take for a disequilibrium in the foreign exchange market to disappear. The evidence in Table 3 above shows that the undervaluation of the euro against sterling on a PPP basis has persisted for the two decades that the euro has existed. Further, there are two reasons to suppose that the undervaluation of the euro will continue to persist for some time.

First, the euro is undervalued because it is a structurally incomplete currency, as explained in Managing Euro Risk. But

47 Jacob A. Frenkel (1976) A monetary approach to the exchange rate: Doctrinal aspects and empirical evidence, Scandinavian Journal of Economics, 78(2), 200-224;

Irving B. Kravis, Alan W. Heston, and Robert Summers (1982) World Product and Income, Baltimore: Johns Hopkins University Press; Irving B. Kravis and Robert E. Lipsey (1978) Price behavior in the light of balance of payments theories, Journal of International Economics, 8(2), 193-246;

Irving B. Kravis and Robert E. Lipsey (1982) Toward an Explanation of National Price Levels, Princeton Studies in International Finance No. 52, Princeton, NJ: International Finance Center, Princeton University; Irving B. Kravis and Robert E. Lipsey (1987) The assessment of national price levels, in Sven W. Arndt and J. David Richardson (eds) Real Financial Linkages Among Open Economies, Cambridge, MA: MIT Press, 97-134; Irving B. Kravis and Robert E. Lipsey (1988) National price levels and the prices of tradeables and non- tradeables, American Economic Review, May 1988 (Papers and Proceedings), 78, 474-8.

48 Rudiger Dornbusch (1976) Expectations and exchange rate dynamics, Journal of Political Economy, 84, 1161-74;

Rudiger Dornbusch (1987) Exchange rates and prices, American Economic Review, 77(1), 93-106.

49 Robert E. Lucas (1978) Asset prices in an exchange economy, Econometrica, 46(6), 1429-45.

50 Alan C. Stockman (1978) The equilibrium approach to exchange rates, Federal Reserve Bank of Richmond Economic Review, March/April, 12-30. even introducing measures that reduced this incompleteness - joint-and-several liability between member states, a lender of last resort, a EZ-wide bank deposit insurance scheme, etc - would be insufficient to remove the undervaluation in full. Only when the EZ members form themselves into a fully federal state, with political and fiscal union - and associated fiscal transfers from richer to poorer regions - can we expect to see the euro's undervaluation on account of its structural incompleteness disappear. The cause of the euro's undervaluation, in this case, is political not economic. The benefits of this lacuna go to the northern EZ states with internal and external trade surpluses, while the costs and risks are borne by the southern EZ states and the ROW.

Second, there is an economic reason explaining the euro's persistent undervaluation that is not related to a disequilibrium in the foreign exchange market. Kravis and Lipsey $(1983,1987,1988)$ found that most cross-country deviations from PPP could be explained by differences in per capita real GDP, i.e., by differences in productivity. This finding is confirmed for European countries by Berka and Devereux (2010).$^{51}$ They show that 'there are large and persistent deviations from absolute PPP among all European countries. The deviations have not been eliminated by membership of the single currency area. Even among Eurozone members, there are persistent departures from PPP that show no obvious signs of erosion within the sample'. Particularly significant is the finding that 'real exchange rates are very closely tied to relative GDP per capita, both in comparisons across countries, and in movement over time, at all levels of aggregation. The data show that some countries displayed declining relative GDP per capita over time, combined with persistent depreciation in their real exchange rate - in particular, this applied to the "Old-Europe" countries - France, Germany, the Netherlands, Belgium, and Austria - while other countries displayed substantial appreciation combined with increasing relative GDP per capita - notably Ireland, the UK, some Scandinavian countries, as well as many countries of emerging Eastern Europe'. Further, 'a one percent increase in the relative GDP per capita for a given country towards the European average leads to a 0.35 to 0.40 percent appreciation of the real exchange rate to the European average'.

These findings are consistent with the Balassa-Samuelson model ${ }^{52}$ which uses productivity differences to explain systematic differences in prices and wages between countries, as well as systematic differences between national incomes (expressed in a common currency) and their PPP values. The model predicts that if real exchange rate differentials are driven primarily by differences in income per capita (i.e., productivity), countries with GDP per capita equal to the EU average should have real exchange rates at the EU average (i.e., PPP should hold). Countries with lower (higher) than average relative GDP should have lower (higher) real exchange rates. Further, for a country that begins with a GDP

51 Martin Berka and Michael B. Devereux (2010) What Determines European Real Exchange Rates?, Working Paper, Massey University and University of British Columbia, 16 July.

52 Bela Balassa (1964) The purchasing power parity doctrine: A reappraisal, Journal of Political Economy, 72, 584-596;

Paul A. Samuelson (1964) Theoretical notes on trade problems, Review of Economics and Statistics, 46, 145-154. 


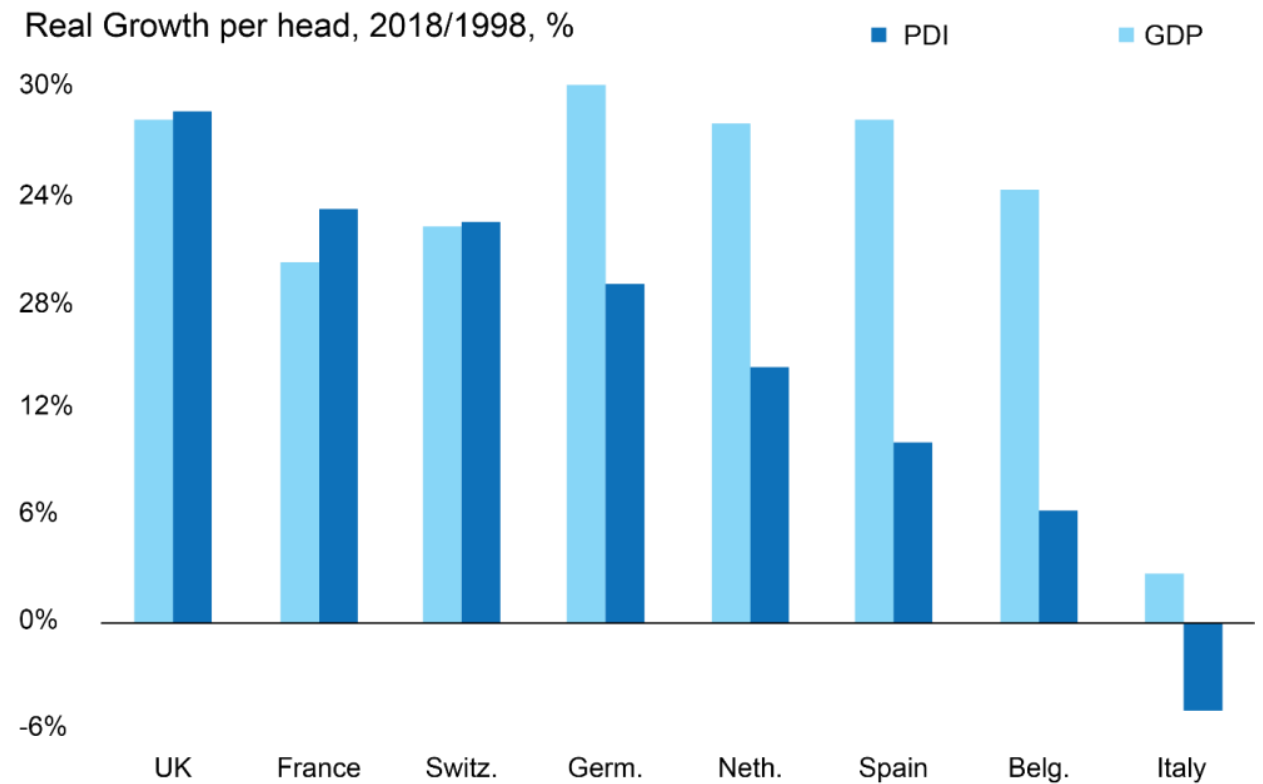

Fig. (12). Real per capita growth in GDP and PDI (after-tax personal disposable income) in selected European countries, $1998-2018$.

per capita below the average, relative GDP per capita should be below the real exchange rate. But if the country catches up and overtakes the average, its relative GDP per capita should cross the real exchange rate from below and converge to a position where relative GDP per capita is above the real exchange rate. The opposite should hold for a country with falling relative GDP per capita.

This is broadly what Berka and Devereux (op. cit.) find over their data period (1995-2007):

- Real exchange rates are positively correlated with real per capita GDP. Over the data period, Belgium, Germany, France, Austria and the Netherlands all have GDP per capita close to the EU average, and the same holds for their real exchange rates. For Greece, Spain, Portugal and (for most of the period) Italy, real exchange rates and relative GDPs per capita were considerably below the EU average, while the Scandinavian countries and (for most of the period) the UK, both real GDP per capita and real exchange rates were substantially above the EU average.

- Movements in relative GDP per capita tend to be associated with movements in real exchange rates in the same direction. This is particularly true for the floating exchange rate countries, i.e., Sweden, UK, Iceland, Norway and Switzerland.

- Once a country joins the euro, its nominal exchange rate relative to other EZ members cannot change, but its real exchange rate can change if nominal prices are slow to adjust. Germany, France, Austria and to a lesser extent Belgium and the Netherlands experienced substantial real exchange rate depreciation after joining the EZ, while Ireland, Italy, Spain and Portugal went through real exchange rate appreciation.
Fig. (12) provides some more recent information which covers the full period of the euro's existence up to $2018 .^{53}$ Particularly striking is the observation that over the period, UK and German real per capita GDP both grew by a total of around $30 \%$, but, while real per capita personal disposable income (PDI) grew by the same amount in the UK, it grew by only $19 \%$ in Germany. In other words, German wages have been held down very severely compared with those in the UK. The situation has been even worse in the Netherlands, Spain, Belgium and, especially Italy, where real PDI has fallen by $6 \%$ since the euro was introduced.

How is this possible? There are a number of explanations.

First, in Germany, there was the 2003 labour market and welfare reform package - known as the Hartz plan or Agenda 2010 - introduced by chancellor Gerhard Schröder. Designed to reduce unemployment from $11.6 \%$ and kickstart the German economy, the reforms included: cuts in welfare benefits, reducing the amount of time unemployment benefits could be drawn, making it easier to hire and fire workers, allowing more part-time and temporary work, and tax breaks to workers and corporations. ${ }^{54}$ These reforms reduced unemployment, but also the growth in real wages.

Second, high unemployment rates have depressed real wage growth in the EZ. Across the EZ, the unemployment rate is $7.5 \%$. It is $16.6 \%$ in Greece, $13.9 \%$ in Spain, $9.7 \%$ in Italy, $8.6 \%$ in France, and $7.7 \%$ in Cyprus. This compares with $2.5 \%$ in Switzerland, 2.2\% in Japan, 3.5\% in the US and $3.8 \%$ in the UK. Within the EZ, only the Netherlands at $3.2 \%$ and Germany at $3.1 \%$ have comparable low figures the latter case showing the success of the Schröder reforms

53 Source: OECD Economic Outlook. See also OECD Economic Outlook, volume 2018, issue 2, on decoupling wages from productivity. 54 Rebecca Staudenmaier (2017) German issues in a nutshell: 'Agenda 2010', DW, 6 June; https://www.dw.com/en/german-issues-in-a-nutshellagenda-2010/a-38789461 
in reducing unemployment. ${ }^{55}$ The rate of youth unemployment is considerably worse. It is $15.6 \%$ across the Eurozone. It is $35.6 \%$ in Greece, $32.1 \%$ in Spain, $28.6 \%$ in Italy, $18.9 \%$ in France, and $17.2 \%$ in Cyprus. This compares with $2.4 \%$ in Switzerland, 3.8\% in Japan, $8.1 \%$ in the US and $11.4 \%$ in the UK. Even the Netherlands at $6.7 \%$ and Germany at $5.9 \%$ have a significant problem with youth unemployment. ${ }^{56}$

A third explanation lies in EU directives and European Court of Justice (ECJ) rulings which favour employers' rights over workers' rights and help to suppress wages in the EU. ${ }^{57}$ Three examples will demonstrate this.

Employees in one member state are prevented from picketing or striking in protest against the use of imported cheaper workers. This follows from the Laval and Viking cases in 2007. In the former case, the Swedish building workers union was found to have acted unlawfully when it picketed a construction company that was employing Latvian workers who were paid $40 \%$ less. The latter case involved Estonian workers undercutting Finnish workers. In the Rüffert case in 2008, the German state of Lower Saxony contracted a company to build a prison on the condition that it paid workers the collectively-agreed minimum wage for the sector. But the company brought in workers from Poland and paid them 54\% less. Lower Saxony tried to cancel the contract, but the ECJ ruled that this restricted the company's right to provide cross-border services. As another German example, in 2005, Volkswagen told the workers at its Wolfsburg factories that it would move production to Poland unless they accepted a three-hour increase in the working week without any increase in pay (effectively an $8 \%$ pay cut). The unions had no alternative but to agree to the demand.

Fig. (12) shows the consequences of these explanations for incomes across the whole EZ. The effect of the directives and rulings, in particular, has allowed EZ companies to use cheap labour in the EZ (both directly and to produce cheap components) to make finished products that undercut the prices of products in international markets. Part of the explanation for the improved trade balance in Italy and Spain after 2012 (Figs. 4 and 5) is the sale of cheap components to other EZ states such as Germany; these components are cheap because as Fig. (12) shows they are made by workers whose real wages have been severely constrained for the last 20 years. This is in addition to the competitive advantage from an undervalued euro. Producers in countries like the UK therefore face a double whammy from EZ imports which are being dumped onto the UK market - where dumping is being used in both the original OECD definition and our proposed additional definition. The systematic decline in UK manufacturing as a share of GDP seen in Fig. (10) is a direct consequence of this: UK manufacturers are simply unable to com-

55 https://tradingeconomics.com/country-list/unemployment-rate. Accessed $26 / 01 / 20$

56 https://tradingeconomics.com/country-list/youth-unemployment-rate. Accessed 26/01/20.

57 As explained in David Blake (2019) The Single Market isn't working why doesn't the Left understand this?, Briefings for Britain, 2 November; https://briefingsforbritain.co.uk/the-single-market-isnt-working-why-doesntthe-left-understand-this/ pete effectively against the cheap labour and components available to German manufacturers.

Following Brexit, UK producers face a third whammy in the form of rules of origin (ROO). EU products are made predominantly using inputs acquired from within the EU, not imported from abroad. They thereby benefit from ROO requirements which specify high levels of local components, reducing the negative impact that a structurally low euro value has on raising the cost of imported components. This reinforces the explanation as to why EZ products are cheap when they are sold abroad. British products by contrast are disadvantaged because a much higher percentage of raw materials have to be imported. To illustrate, only $25 \%$ of the parts in a UK built car are purchased in the UK, the rest are imported. Accordingly, the UK may suffer from tight ROO requirements for cars in a future free trade agreement (FTA) with a partner such as the US which tends to require high threshold ROO, perhaps exceeding 55\%.

\section{POTENTIAL REMEDIES UNDER INTERNATION- AL LAW ${ }^{58}$}

The structurally undervalued euro potentially violates two areas of international law: dumping and subsidies.

First, Article VI of the General Agreement on Tariffs and Trade (GATT) points out that multiple currency practices can 'constitute a form of dumping by means of a partial depreciation of a country's currency', thereby benefitting EZ exporters unfairly. The anti-dumping remedy in this case is the imposition by the importing state of an additional duty on the dumped goods. One method of determining the size of the additional tariff would be the World Trade Organization (WTO)'s Anti-Dumping Agreement (ADA) using the surrogate price method..$^{59}$

Second, artificially low currencies could amount to an export subsidy and therefore breach the WTO's Agreement on Subsidies and Countervailing Measures (SCM). ${ }^{60,61}$ The US Department of Commerce has announced that it intends to impose countervailing duties on products which benefit from unfair currency subsidies. ${ }^{62}$ In addition, southern EZ coun-

58 I am grateful to Professor David Collins and Barney Reynolds for discussions on this section. The usual caveat applies. For a fuller analysis of the ideas in this section, see David Collins (2020) How to Level the EU's Playing Field: Trade Remedies for a Trade Deal, Politeia;

https://www.politeia.co.uk/how-to-level-the-eus-playing-field-traderemedies-for-a-trade-deal-by-david-collins/

59 The normal value of the product is assessed by reference to what it is in a third country which is not a currency manipulator.

60 E.g., A. de Lima-Campos and J. A. Gaviria (2012), A case for misaligned currencies as countervailable subsidies, Journal of World Trade, 46, 1017, and B. B. Caryl (2011), Is China currency regime a countervailable subsidy? A legal analysis under the World Trade Organization's SCM Agreement, Journal of World Trade, 45,187-219.

61 Daniel Stelter argues that the euro is a 'subsidy for our export-oriented industries which we finance ourselves by giving credit to our international customers, even though most of the latter will never be in a position to pay this credit back', quoted in Will Italy Spell the End of the Euro?, The Globalist, 22 May 2018; https://www.theglobalist.com/italy-elections-eurozoneecb-economy/

62 US Department of Commerce (2020), Department of Commerce Issues Final Rule for Countervailing Unfair Currency Subsidies, 4 February; 
tries are indirectly subsidising cheap German and other northern state exports, not only by producing cheap components made by workers on falling real wages, but also dragging down the international value of the euro relative to the DEM.

The evidence needed to establish that a subsidy exists is outlined in Article 1 of the SCM which specifies that a subsidy exists if:

(a) there is a financial contribution by a government or any public body;

(b) a benefit is thereby conferred; and

(c) the subsidy is specific to an enterprise or industry or group of enterprises.

There is a question mark over whether an undervalued euro would meet the 'specificity' requirement, since the whole economy benefits rather than a specific enterprise or industry. However, some have argued that an undervalued exchange rate constitutes an export subsidy with the remedy under WTO rules being countervailing measures to offset the extent of the subsidy. ${ }^{63}$

Our PPP evidence provides a useful way of calculating the size of the anti-dumping or countervailing duty, avoiding any difficulties associated with estimating surrogate prices. The data in Table 3 shows that on a PPP basis, the euro was undervalued against sterling by between $15.2 \%$ and $20 \%$. Given that EZ exports to the UK were $£ 303.9$ bn in $2018,{ }^{64}$ and given the UK has an import price elasticity of $-1.455,{ }^{65}$ this means that, had the euro been correctly valued, EZ exports to the UK in 2018 would have been lower by between $£ 67.2 \mathrm{bn}^{66}$ and $£ 88.4 \mathrm{bn} .{ }^{67}$ The UK would therefore be entitled to impose an annual anti-dumping or countervailing duty on the EZ in the range $£ 67.2 \mathrm{bn}-£ 88$.4bn (based on 2018 export figures).

\section{CONCLUSION}

We have provided powerful economic evidence that the euro is persistently structurally undervalued and that as a consequence, the EZ, in general, and Germany and the Netherlands, in particular, are dumping goods at below fair market values onto world markets, in general, and the UK, in particular. We estimate that the euro is undervalued against sterling by between $15.2 \%$ and $20 \%$, and that had the euro been correctly valued, then EZ exports to the UK in 2018 would have been lower by between $£ 67.2$ bn and $£ 88$.4bn. The UK

https:/www.commerce.gov/news/press-releases/2020/02/departmentcommerce-issues-final-rule-countervailing-unfair-currency.

63Aaditya Mattoo and Arvind Subramanian (2009), Currency undervaluation and sovereign wealth funds: A new role for the World Trade Organization, The World Economy, 32, 1135-1164.

64 https://researchbriefings.files.parliament.uk/documents/CBP-7851/CBP7851.pdf.

65This measures the percentage reduction in imports for every one percent rise in import prices. Source: Table 2 in Jean Imbs and Isabelle Méjean (2010) Trade Elasticities: A Final Report for the European Commission, European Commission, July;

https://ec.europa.eu/economy finance/publications/economic paper/2010/p df/ecp432_en.pdf.

$6615.2 \% \times 1.455 \times £ 303.9 \mathrm{bn}$.

$6720 \% \times 1.455 \times £ 303.9 \mathrm{bn}$. would therefore be entitled to impose an annual antidumping or countervailing duty on the EZ in the range $£ 67.2 \mathrm{bn}-£ 88.4 \mathrm{bn}$. The euro also acts as a subsidy to firms from within these countries, giving them an unfair advantage over global competitors. The subsidy is reinforced by EU directives and ECJ rulings which have driven down real wages in the richer parts of the EU in the presence of intense competition from low-wage workers in the poorer parts of the EU.

The EU is following a classic 'beggar thy neighbour'68 ${ }^{6}$ strategy. This is where a country or trading bloc follows a protectionist trade strategy that adversely affects its trading partners. Typically, this involves tools such as tariffs and quotas. But in this case, the weapon is a structurally undervalued currency.

This assessment was supported in 2017 by Peter Navarro, then US President Donald Trump's trade adviser, during the negotiation of the (ultimately aborted) US-EU FTA, the Transatlantic Trade and Investment Partnership (TTIP). He accused Germany of using a 'grossly undervalued' euro to 'exploit' both the US and its own EU partners: 'A big obstacle to viewing TTIP as a bilateral deal is Germany, which continues to exploit other countries in the EU as well as the US with an "implicit Deutsche Mark" that is grossly undervalued. The German structural imbalance in trade with the rest of the EU and the US underscores the economic heterogeneity within the EU - ergo, this is a multilateral deal in bilateral dress', 69

The UK government has introduced the 2021 Trade Act which established a new Trade Remedies Authority to prevent countries from dumping cheap goods onto the UK market, potentially putting key domestic industries, like steel, out of business. The Trade Remedies Authority will enable the UK to conduct its own dumping and subsidies investigations. The Act may have been intended to target China in particular, ${ }^{70}$ but trade remedies can be levied against any WTO member, including the EU, whether or not there is an FTA in place.

We have made two striking findings. The first is that we have been able to quantify the degree of euro undervaluation against sterling, at between $15.2 \%$ and $20 \%$. The second comes from the study by Michael Burrage and Phil Radford which showed that over the period of the euro's existence, UK exports to the rest of the world grew approximately six times faster than UK exports to the Eurozone - proving conclusively that the UK's falling relative share of trade with the EZ is primarily caused by an undervalued euro. These findings were not the result of sophisticated economic modelling, rather they are obvious from a straightforward examination of publicly available data from the OECD and the UK Office for National Statistics. These findings ought to be

68https://www.investopedia.com/terms/b/beggarthyneighbor.asp. 69US trade chief seeks to reshore supply chain', Financial Times, 31 January 2017; https:// www.ft.com/content/8dc63502-e7c7-11e6-893c$082 \mathrm{c} 54 \mathrm{a} 7 \mathrm{f} 539$

70Richard Vaughan (2005), Ministers to table trade bill to protect UK industry from China dumping cheap goods, The Independent, 5 February; https://inews.co.uk/news/politics/brexit/trade-bill-exclusive-uk-chinaindustry-dumping-goods-1386403. 
well known, not only in the UK, but also in the EU and beyond. But they are not.

Instead, we are told that the EU 'held all the cards' in the trade negotiations with the UK that led to the Trade and Cooperation Agreement (TCA). European Commission President Ursula von der Leyen said the EU was 'ready to design a new partnership with zero tariffs, zero quotas, zero dumping' with the UK. ${ }^{71}$ The TCA will have the effect of permanently advantaging Germany and other EZ member state beneficiaries of the euro's systematic undervaluation to the detriment of the UK, continuing an arrangement that is demonstrably unfair to the UK.

It is quite remarkable that the new German president of the European Commission called for zero dumping, when her own country is one of the world's biggest dumpers of goods onto world markets. ${ }^{72}$ Equally remarkable is the deafening silence of influential organisations in the UK, like the Treasury, the Bank of England, the Confederation of British Industry, and especially the British Broadcasting Corporation, which has enabled the myth that the EU holds all the cards to be perpetuated for so long. Coincidentally, all these organisations wanted the UK to remain in the EU.

In March 2021, China introduced anti-dumping duties of between $116.2 \%$ and $218.4 \%$ on imports of Australian wine. ${ }^{73}$ Unless the UK government takes similar measures on goods imports to the UK from the EU, UK producers will continue to be disadvantaged by the undervalued euro and UK manufacturing will continue to decline to levels that will put UK's future economic security at risk. We have seen in the last year, two striking examples of the risks of relying on overseas manufacturers for critical products: first, the problems of getting personal protective equipment for hospital workers at the beginning of the coronavirus pandemic - virtually no PPE was manufactured in the UK - and, second, the treatment of AstraZeneca by the European Commission which blocked the export to the UK of the AZ vaccine being manufactured at a plant in the Netherlands, despite having a valid legally agreed contract and despite the UK government investing $\$ 20 \mathrm{~m}$ in the plant, while the EU invested nothing.74 The UK needs to act now in the same way that China has.

\section{CONFLICT OF INTEREST STATEMENT}

The authors declare that they have no conflict of interest.

71Speech at the London School of Economics, 8 January 2020; https://ec.europa.eu/commission/presscorner/detail/en/speech_20_3

72 This is a practice that Germany has followed consistently since the 1870 s. See: Thomas R. Howell and Dewey Ballantine (1997) 'Dumping: Still a Problem' in Charles W. Wessner (Editor) International Trade in International Friction and Cooperation in High-Technology Development and Trade: Papers and Proceedings, Washington DC: National Academy Press; https://www.nap.edu/read/5902/chapter/28. On p332, it is stated that 'It was the standard practice of ...German kartells to engage in large-scale dumping as a deliberate export strategy', citing Witness No. 11, Report of the Tariff Commission, Vol. I (London: P.S. King \& Son, 1904), pars. 795, 806. 73https://www.bloomberg.com/news/articles/2021-03-26/china-s-tariffs-onaustralian-wine-to-last-5-years-as-ties-sour

74https://www.dailymail.co.uk/news/article-9429095/UK-taxpayerspumped-21m-fitting-Dutch-vaccine-factory-EU-blocked.html

\section{REFERENCES}

Balassa, B. (1964) The purchasing power parity doctrine: A reappraisal, Journal of Political Economy, 72, 584-596.

Berka, M., and Devereux, M. B. (2010) What Determines European Real Exchange Rates?, Working Paper, Massey University and University of British Columbia, 16 July.

Blake, D. (2018) Target2: The Silent Bailout System that Keeps the Euro Afloat, SSRN, 22 May; https://papers.ssrn.com/sol3/papers.cfm?abstract_id=3182995.

Blake, D. (2019) The Single Market isn't working - why doesn't the Left understand this?, Briefings for Britain, 2 November; https://briefingsforbritain.co.uk/the-single-market-isnt-workingwhy-doesnt-the-left-understand-this/

Blake, D. (2020) Ensuring a genuine level playing field with the EU postBrexit, Briefings for Britain, 28 February;

https://briefingsforbritain.co.uk/ensuring-a-genuine-level-playingfield-with-the-eu-post-brexit/

Burrage, M., and Radford, P. (2020) WTO vs the EU: An Assessment of the Relative Merits of the UK's Trade Relationships 1999-2018, Civitas, June; https://www.civitas.org.uk/publications/wto-vs-the-eu/.

Caryl, B. B. (2011), Is China currency regime a countervailable subsidy? A legal analysis under the World Trade Organization's SCM Agreement, Journal of World Trade, 45,187-219.

Collins, D. (2020) How to Level the EU's Playing Field: Trade Remedies for a Trade Deal, Politeia; https://www.politeia.co.uk/how-tolevel-the-eus-playing-field-trade-remedies-for-a-trade-deal-bydavid-collins/

de Lima-Campos, A., and J. A. Gaviria (2012), A case for misaligned currencies as countervailable subsidies, Journal of World Trade, 46, 1017 ,

Dornbusch, R. (1976) Expectations and exchange rate dynamics, Journal of Political Economy, 84, 1161-74;

Dornbusch, R. (1987) Exchange rates and prices, American Economic Review, 77(1), 93-106.

Elstner, S., Feld, L. P., and Schmidt, C. M. (2018) The German Productivity Paradox - Facts and Explanations, Ruhr Economic Papers \#767, RWI - Leibniz-Institut für Wirtschaftsforschung, Essen, Germany: ISSN 1864-4872.

http://www.rwi-essen.de/media/content/pages/publikationen/ruhreconomic-papers/rep_18_767.pdf.

Frenkel, J. A. (1976) A monetary approach to the exchange rate: Doctrinal aspects and empirical evidence, Scandinavian Journal of Economics, 78(2), 200-224.

Howell, T. R. and Ballantine, D. (1997) 'Dumping: Still a Problem' in Charles W. Wessner (Editor) International Trade in International Friction and Cooperation in High-Technology Development and Trade: Papers and Proceedings, Washington DC: National Academy Press; https://www.nap.edu/read/5902/chapter/28

Imbs, J., and Méjean, I. (2010) Trade Elasticities: A Final Report for the European Commission, European Commission, July; https://ec.europa.eu/economy_finance/publications/economic_pape r/2010/pdf/ecp432_en.pdf.

Kravis, I. B., Heston, A. W., and Summers, R. (1982) World Product and Income, Baltimore: Johns Hopkins University Press.

Kravis, I. B., and Lipsey, R. E. (1978) Price behavior in the light of balance of payments theories, Journal of International Economics, 8(2), 193-246;

Kravis, I. B., and Lipsey, R. E. (1982) Toward an Explanation of National Price Levels, Princeton Studies in International Finance No. 52, Princeton, NJ: International Finance Center, Princeton University;

Kravis, I. B., and Lipsey, R. E. (1987) The assessment of national price levels, in Sven W. Arndt and J. David Richardson (eds) Real Financial Linkages Among Open Economies, Cambridge, MA: MIT Press, 97-134;

Kravis, I. B., and Lipsey, R. E. (1988) National price levels and the prices of tradeables and non- tradeables, American Economic Review, May 1988 (Papers and Proceedings), 78, 474-8.

Mann, J. (2021), A post-Brexit economy needs a lower sterling exchange rate, Briefings for Britain, 4 April; https://www.briefingsforbritain.co.uk/a-post-brexit-economyneeds-a-lower-sterling-exchange-rate

Mattoo, A., and Subramanian, A. (2009), Currency undervaluation and sovereign wealth funds: A new role for the World Trade Organization, The World Economy, 32, 1135-1164. 
Reynolds, B., Blake, D., and Lyddon, R. (2020) Managing Euro Risk, Politeia, 27 February 2020; https://www.politeia.co.uk/managingeuro-risk-saving-investors-from-systemic-risk-by-barnabasreynolds-david-blake-and-robert-lyddon/

Samuelson, P. A. (1964) Theoretical notes on trade problems, Review of Economics and Statistics, 46, 145-154.
Stockman, A. C. (1978) The equilibrium approach to exchange rates, Federal Reserve Bank of Richmond Economic Review, March/April, 1230 .

Received: April 02, 2021

Revised: April 12, 2021

Accepted: July 05, 2021

Copyright $\odot$ 2021- All Rights Reserved

This is an open-access article. 